Hegerl GC, Black E, Allan RP, Ingram WJ, Polson D, Trenberth KE, Chadwick RS, Arkin PA, Sarojini BB, Becker A, Dai AG, Durack PJ, Easterling D, Fowler HJ, Kendon EJ, Huffman GJ, Liu CL, Marsh R, New M, Osborn TJ, Skliris N, Stott PA, Vidale PL, Wijffels SE, Wilcox LJ, Willett KM, Zhang XB. Challenges in Quantifying Changes in the Global Water Cycle. Bulletin of the American Meteorological Society 2015, 96(7), 1097-1115.

\title{
Copyright:
}

(C) Copyright $1^{\text {st }}$ July 2015 American Meteorological Society (AMS). Permission to use figures, tables, and brief excerpts from this work in scientific and educational works is hereby granted provided that the source is acknowledged. Any use of material in this work that is determined to be "fair use" under Section 107 of the U.S. Copyright Act September 2010 Page 2 or that satisfies the conditions specified in Section 108 of the U.S. Copyright Act (17 USC §108, as revised by P.L. 94-553) does not require the AMS's permission. Republication, systematic reproduction, posting in electronic form, such as on a web site or in a searchable database, or other uses of this material, except as exempted by the above statement, requires written permission or a license from the AMS. Additional details are provided in the AMS Copyright Policy, available on the AMS Web site located at (https://www.ametsoc.org/) or from the AMS at 617-227-2425 or copyrights@ametsoc.org.

DOI link to article:

http://dx.doi.org/10.1175/BAMS-D-13-00212.1

Date deposited:

$19 / 08 / 2016$ 


\section{CHALLENGES IN QUANTIFYING CHANGES IN THE GLOBAL WATER CYCLE}

by Gabriele C. Hegerl, Emily Black, Richard P. Allan, William J. Ingram, Debbie Polson, Kevin E. Trenberth, Robin S. Chadwick, Phillip A. Arkin, Beena Balan Sarojini, Andreas Becker, Aiguo Dai, Paul J. Durack, David Easterling, Hayley J. Fowler, Elizabeth J. Kendon, George J. Huffman, Chunlei liu, Robert Marsh, Mark New, Timothy J. Osborn, Nikolaos Skliris, Peter A. Stott, Pier-Luigi Vidale, Susan E. Wijffels, laura J. Wilcox, Kate M. Willett, and Xuebin Zhang

Maintaining and improving observational capabilities is key to understanding human influences on the large-scale water cycle.

C limate change, alongside increased demand for water (World Water Assessment Program 2003; WHO/UNICEF 2011), is projected to increase water scarcity in many regions over the next few decades (e.g., Arnell et al. 2013; Kundzewicz et al. 2007). Extremes linked to the water cycle, such as droughts, heavy rainfall, and floods, already cause substantial damage (e.g., Lazo et al. 2011; Peterson et al. 2012, 2013), and such events are expected to increase in severity and frequency (Dai 2011a, 2013a; Field et al. 2012; Collins et al. 2013).

Better management of water resources and adaptation to expected changes require reliable predictions of the water cycle. Such predictions must be grounded in the changes already observed. This requires quantification of long-term large-scale changes in key water cycle variables and estimation of the contribution from natural climate variability and external forcings, including through studies that are referred to as detection and attribution (see Stott et al. 2010; Hegerl and Zwiers 2011). Successful examples of detection and attribution are reported in Bindoff et al. (2013).
We discuss how well the available observing capability can capture expected changes in the global water cycle, including the increasing water content of the atmosphere, strengthening of climatological precipitation minus evaporation $(P-E)$ patterns, the pronounced spatial structure and sharp gradients in precipitation change, and increases of extreme precipitation. We also discuss the challenges inherent in combining an incomplete observational record with imperfect climate models to detect anthropogenic changes in the water cycle.

Drawing on discussions from a workshop held at the University of Reading, United Kingdom, in June 2012, we focus on long-term large-scale changes in a few key variables that are both potentially related to climate change and are essential for diagnosing changes in the global water cycle. These include humidity, precipitation, $P-E$, and salinity. We also give recommendations that will lead to more robust

Publisher's Note: This article was modified on 14 August 2015 to correct latitudinal labels on the $\mathrm{x}$-axis in Fig. 3. 
predictions and identification of the human influence on recent observed changes. It is beyond the scope of this paper to provide a full review of water cycle changes or to discuss regional changes (see Collins et al. 2013; Sánchez-Lugo et al. 2014), changes in the biosphere and cryosphere, river discharge (see Dai et al. 2009), or drought (see Dai 2011a,b, 2013a; Trenberth et al. 2014).

We briefly describe the expected physical changes before discussing the challenges of observing such changes with present observational capabilities, globally, as well as over ocean and land separately. We also discuss how physically consistent a picture these observations draw and conclude with recommendations to ensure continued and improved ability to document the changing water cycle. The supplement provides more information on available observational data and quality control procedures (supplemental information available online at http:// dx.doi.org/I0.II75/BAMS-D-I3-002I2.2).

\section{EXPECTED CHANGES IN THE GLOBAL} WATER CYCLE. Changes in the hydrological cycle are an expected consequence of anthropogenic climate change. The Clausius-Clapeyron relationship suggests a strong quasi-exponential increase in water vapor concentrations with warming at about $6 \%-7 \% \mathrm{~K}^{-1}$ near the surface. This is consistent with observations of change over the ocean (e.g., Trenberth et al. 2005; Dai 2006; Chung et al. 2014) and land (Willett et al. 2010) and with simulations of future changes (e.g., Allen and Ingram 2002) and assumes that on large scales the relative humidity changes little, as generally expected (see Sherwood et al. 2010; Allen and Ingram 2002) and approximately seen in models (Richter and Xie 2008; Collins et al. 2013). Locally, however, relative humidity changes may arise where large-scale circulation patterns alter or when moisture sources are limited over land (e.g., Dai 2006; Vicente-Serrano et al. 2014).

Changes in global-mean precipitation are limited by the energy budget, both through evaporation and the ability of the atmosphere to radiate away the latent heat released when precipitation forms (e.g., Trenberth 2011; O'Gorman et al. 2012). This largely explains why global-mean precipitation increases by only $2 \%-3 \% \mathrm{~K}^{-1}$ of warming in climate models (the "hydrological sensitivity"; see Fig. 1). Broadly, the radiative effect of greenhouse gas forcing reduces the global precipitation increase driven by warming itself (e.g., Bony et al. 2013), while the direct radiative effect of aerosols that scatter rather than absorb sunlight does not influence the rate at which precipitation increases with warming. Figure 1 illustrates this for climate models run under the Coupled Model Intercomparison Project phase 5 (CMIP5) protocol (Taylor et al. 2012) for the twentieth century and for four standard scenarios for the twenty-first century. These range from representative concentration pathway 8.5 (RCP8.5)a high emissions scenario, to RCP2.6, a low emissions scenario (see Collins et al. 2013). With stronger greenhouse gas forcing, global-mean temperature and precipitation both increase more, but the hydrological sensitivity becomes slightly smaller (see also Wu et al. 2010; Johns et al. 2011). Pendergrass and
AfFILIATIONS: HegerL AND POLSON-School of GeoSciences, University of Edinburgh, Grant Institute, United Kingdom; BLACK, Allan, SarojinI, LIU, VIDALE, AND WILCOX-Department of Meteorology, University of Reading/National Centre for Atmospheric Science Climate, Reading, United Kingdom; INGRAM-Met Office Hadley Centre, Exeter, and Department of Physics, Oxford University, Oxford, United Kingdom; TrenberTH-National Center for Atmospheric Research,* Boulder, Colorado; Chadwick, Kendon, Stott, and Willett-Met Office Hadley Centre, Exeter, United Kingdom; ARKIN-Earth System Science Interdisciplinary Center, University of Maryland, College Park, College Park, Maryland; BECKERDeutscher Wetterdienst, Offenbach, Germany; DAl-Department of Atmospheric and Environmental Sciences, University at Albany, State University of New York, Albany, New York, and National Center for Atmospheric Research,* Boulder, Colorado; DURACKProgram for Climate Model Diagnosis and Intercomparison, Lawrence Livermore National Laboratory, Livermore, California, and Commonwealth Scientific and Industrial Research Organisation, Hobart, Tasmania, Australia; EASTERLING - NOAA/National Climatic Data Center, Asheville, North Carolina; Fowler-School of Civil Engineering and Geosciences, Newcastle University, Newcastle upon Tyne, United Kingdom; HufFMAN-NASA Goddard Space
Flight Center, Greenbelt, Maryland; MARSH AND SKLIRIS—Ocean and Earth Science, University of Southampton, Southampton, United Kingdom; New-University of Cape Town, Rondebosch, Cape Town, South Africa; OsBorN-Climatic Research Unit, School of Environmental Sciences, University of East Anglia, Norfolk, United Kingdom; WIJFFELS-Commonwealth Scientific and Industrial Research Organisation, Hobart, Tasmania, Australia; ZHANG-Climate Research Division, Environment Canada, Toronto, Ontario, Canada * The National Center For Atmospheric Research is sponsored by the National Science Foundation.

CORRESPONDING AUTHOR: Gabriele Hegerl, GeoSciences, Grant Institute, Kings Buildings, James Hutton Rd, Edinburgh EH9 3FE, United Kingdom

E-mail: gabi.hegerl@ed.ac.uk

The abstract for this article can be found in this issue, following the table of contents.

DOI: | 0. I |75/BAMS-D-|3-002 |2. I

A supplement to this article is available online (10.1I75/BAMS-D-13-00212.2)

In final form 26 September 2014

(O2015 American Meteorological Society 

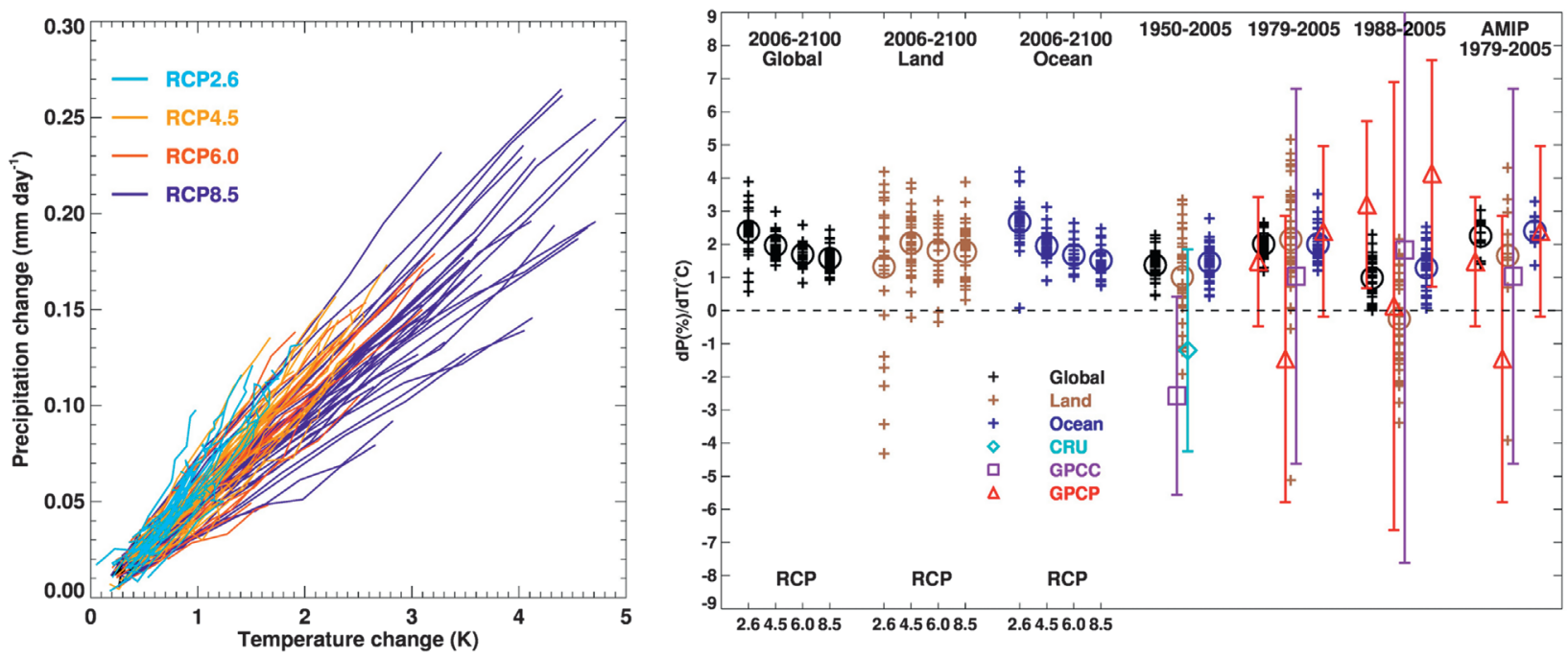

Fig. I. (left) Projected global-mean precipitation change $\left(\mathrm{mm}^{\mathrm{day}}{ }^{-1}\right)$ against global-mean 2-m air temperature change (K) from CMIP5 models for four RCP scenarios. Values are means over successive decades between 2006 and 2095 and all ensemble members of each model. Anomalies are relative to mean values over 1986-2005 in the CMIP5 historical runs. (right) Precipitation sensitivity for future (RCP scenarios) and past [Historical and Atmospheric Model Intercomparison Project (AMIP)] change in precipitation amount (\%) per degree of global-mean warming. Trends are calculated from the linear least squares fit of annual global-mean precipitation change (\%) against temperature (K) change relative to the period 1988-2005 (without decadal smoothing). Crosses indicate ensemble means for each CMIP5 model; circles indicate the multimodel mean. Precipitation sensitivity is also shown for historical periods, comparing GCMs with GPCP, GPCC, and CRU data (see text), and using temperature changes from HadCRUT4 (Morice et al. 2012; note that land and ocean dP/dT values use global-mean temperature). Whiskers indicate $95 \%$ confidence intervals for observed linear trends (model trend confidence intervals are not shown, but are often large).

Hartmann (2014) show that the spread in the CMIP5 model response of precipitation to increases in carbon dioxide is related to differences in atmospheric radiative cooling, which are in turn related to changes in temperature profiles and water vapor amounts. Forced changes in global-mean precipitation are expected to be relatively small at present (Fig. 1b) and are therefore hard to distinguish from natural variability.

Spatial patterns are important both for identifying fingerprints of forced changes in precipitation and for impacts. Since global-mean evaporation and precipitation are expected to increase more slowly with temperature than implied by water vapor content, this implies slightly increased water vapor residence times and reduced atmospheric mass convergence (Vecchi et al. 2006; Held and Soden 2006). However, increasing water vapor more than offsets the weakened atmospheric wind convergence in the tropics (Vecchi et al. 2006; Held and Soden 2006; Allan 2012; Kitoh et al. 2013). Thus, where $E$ exceeds $P$ in the mean (such as over the subtropical oceans), it would do so even more, while areas where $P$ exceeds $E$ [e.g., the intertropical convergence zone (ITCZ) and high latitudes] would receive yet more precipitation excess (Manabe and Wetherald 1980; Held and Soden 2006; Seager and
Naik 2012; Bengtsson et al. 2011; Bintanja and Selten 2014). Simulations of future climate changes broadly confirm this, particularly when zonally averaged (see Fig. 2, bottom) and show rainfall generally increasing at latitudes and seasons that currently have high rainfall and less in dry regions (Collins et al. 2013). This "wet get wetter, dry get drier" paradigm involves a range of atmospheric processes, including an increased vertical gradient of atmospheric water vapor, which leads to intensified convective events in the deep tropics (see Chou et al. 2009).

However, simple $P-E$ enhancement does not necessarily apply to dry land, where moisture is limited (Greve et al. 2014). It also does not hold true at regional scales, where atmospheric circulation changes may displace the geographical positions of "wet" and "dry" regions (Xie et al. 2010; Chadwick et al. 2013; Allan 2014). General circulation models (GCMs) generally simulate an expansion of the Hadley cells as the globe warms, with associated poleward migration of subtropical aridity and storm tracks, but the size varies and there is limited agreement on the mechanisms (Yin 2005; Lu et al. 2007; Seidel et al. 2008; Scheff and Frierson 2012a,b).

Anthropogenic aerosol effects counteract some of the anticipated greenhouse gas-driven warming 


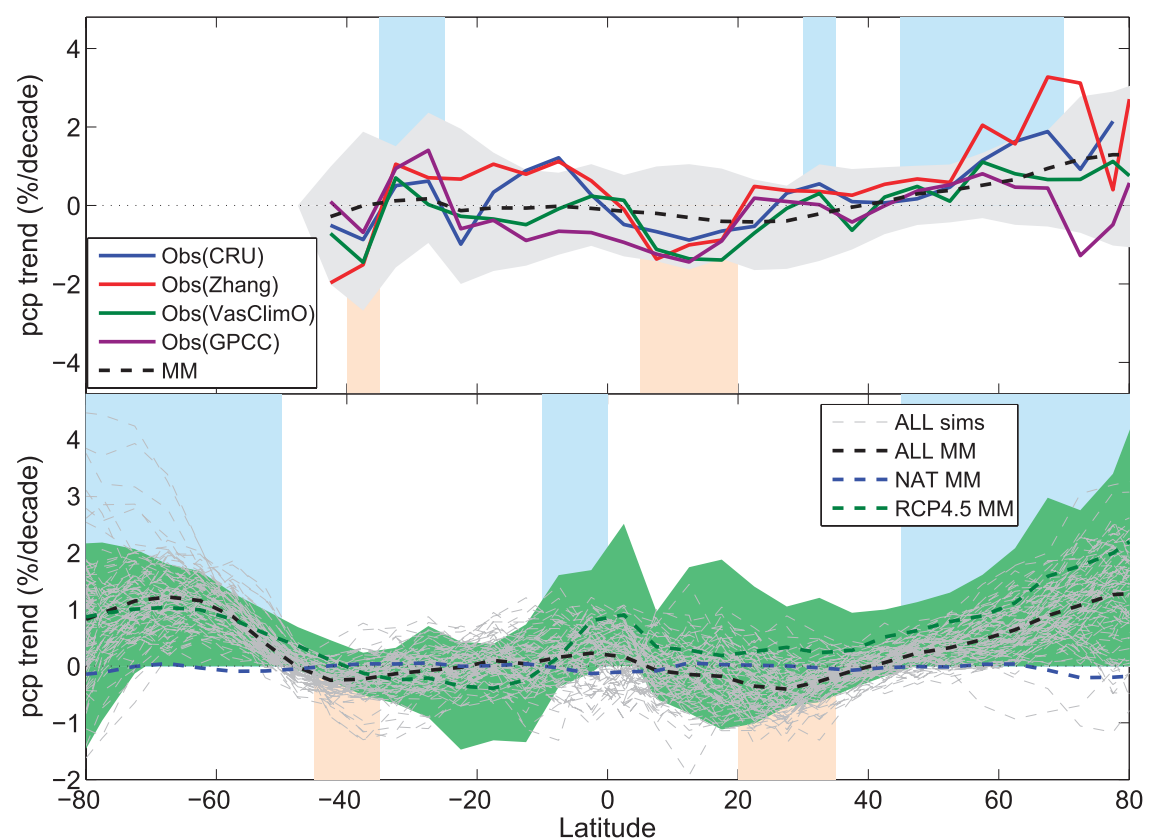

FIG. 2. Observed and model-simulated annual- and zonal-mean precipitation change (\% decade ${ }^{-1}$ ) for observations where they exist over land and GCMs, all grid boxes. (top) Observed 195I-2005 changes (solid colored lines) from four datasets [CRU updated, Harris et al. (2014); Zhang et al. (2007) updated; GPCC VASClimO, Beck et al. (2005); and GPCC full data V6, Becker et al. (20I3)]. Range of CMIP5 model simulations (gray shading, masked to cover land only) and multimodel ensemble mean (black dashed, MM). Blue shading shows latitudes where all observed datasets show positive trends and orange shading shows where all show negative trends. Interpolated data in the CRU dataset are masked out. (bottom) Trends based on global coverage from climate models from the historical simulations (gray dashed lines are individual simulations, black dashed line multimodel mean; blue dashes multimodel mean from simulations forced by natural forcing only) compared to the 2006-50 trend from the RCP4.5 multimodel simulations (green shading shows the 5\%-95\% range, green dashes show the multimodel mean). Blue (orange) shading indicates where more than two-thirds of the historical simulations show positive (negative) trends.

and hence the associated increase in precipitation (Liepert et al. 2004; Wu et al. 2013). Aerosols reduce the available energy for evaporation, and absorbing aerosols such as black carbon locally heat the atmosphere, effectively short-circuiting the hydrological cycle. Pendergrass and Hartmann (2012) show how black carbon forcing influences the intermodel spread in global-mean precipitation change in the Coupled Model Intercomparison Project phase 3 (CMIP3) models. The aerosol indirect effect may account for almost all aerosol cooling in models (Zelinka et al. 2014) and so is a key to the aerosol-driven decrease in precipitation (Liepert et al. 2004; H. Levy et al. 2013), although this is model dependent (e.g., Shindell et al. 2012). The radiative effect of anthropogenic aerosols is also expected to affect the spatial pattern of precipitation and evaporation changes. As surface emissions of aerosol are spatially heterogeneous and atmospheric residence times are relatively short, the direct radiative impact of aerosol is geographically variable, with the largest concentrations in the Northern Hemisphere $(\mathrm{NH})$. The geographical heterogeneity of aerosol distribution is expected to affect the interhemispheric temperature gradient and hence the atmospheric circulation, which should shift the ITCZ (e.g., Rotstayn et al. 2000; Ming and Ramaswamy 2011; Hwang et al. 2013) and change the width of the Hadley cell (Allen et al. 2012). Models' representation of aerosols, and their interactions with clouds in particular, affects their ability to reproduce trends in the interhemispheric temperature gradient (e.g., Chang et al. 2011; Wilcox et al. 2013). Modeling studies also suggest that aerosols may have contributed to the drying of the Sahel from 1940 to 1980 (Rotstayn and Lohmann 2002; Ackerley et al. 2011; Hwang et al. 2013; Dong et al. 2014) and influence the East Asian monsoon (e.g., Lau et al. 2006; Meehl et al. 2008; Guo et al. 2012; Polson et al. 2014) and midlatitude precipitation (Leibensperger et al. 2012; Rotstayn et al. 2012).

Stratospheric aerosols from explosive volcanic eruptions also influence the water cycle. Sharp reductions in observed global-mean land precipitation and streamflow were observed after the Mt. Pinatubo eruption in 1991 (Trenberth and Dai 2007) and other twentieth-century eruptions (Gu et al. 2007). This effect is particularly evident in climatologically wet regions, where the observed reduction in precipitation following eruptions appears significantly larger than simulated (Iles and Hegerl 2014). Volcanoes may also contribute to regional drought by influencing the interhemispheric energy budget (e.g., Haywood et al. 2013). 
OBSERVING ANDATTRIBUTING CHANGES IN THE GLOBAL-SCALE WATER CYCLE. Increases in atmospheric moisture are a key fingerprint of climate change. Surface specific humidity at global scales is reasonably well observed over land since 1973 [Met Office Hadley Centre Integrated Surface Database for Humidity (HadISDH); Willett et al. 2013] and over ocean since 1971 [National Oceanography Centre, Southampton Flux Dataset v2.0 with voluntary observing ships (NOCSv2.0); Berry and Kent 2009, 2011] using in situ data (for measurement techniques and more background as well as dataset information, see the supplement), and results are quite robust across different data products (e.g., Dai 2006; Willett et al. 2007, 2013). Combined land and ocean surface specific humidity over the 1973-99 period shows widespread increases. This change has been attributed mainly to human influence (Willett et al. 2007). As expected, globally, changes in relative humidity between 1973 and 1999 are small or negative (Hartmann et al. 2013). Since 2000, however, a decrease has been observed over land-likely related to the greater warming of land relative to the ocean (Joshi et al. 2008; Simmons et al. 2010; Willett et al. 2014).

In situ measurements of atmospheric humidity from radiosonde data provide time series of total column water vapor (TCWV) from the 1950s. Increasing water vapor is apparent although spatial sampling is limited and temporal inhomogeneities are problematic (Zhao et al. 2012). Global-scale patterns of change became observable only when the satellite era began. Since the 1980s, near-global satellite-based estimates of TCWV over the ice-free oceans and of clear-sky upper-tropospheric relative humidity have allowed variability in tropospheric water vapor to be explored (e.g., Trenberth et al. 2005; Chung et al. 2014). The satellite-based Special Sensor Microwave Imager (SSM/I) TCWV data for 1988-2006 have enabled a robust anthropogenic fingerprint of increasing specific humidity to be detected over the oceans (Santer et al. 2007, 2009).

Satellite-based sensors, in combination with in situ data for best results, provide the only practical means for monitoring precipitation over land and ocean combined (e.g., Fig. 1). Satellite precipitation passive retrievals are restricted to the thermal infrared (IR) and microwave (MW) spectral bands. IR-based estimates are available from geostationary satellites at high frequency but have modest skill at instantaneous rainfall intensity (e.g., Kidd and Huffman 2011). Passive MW data, available since mid-1987, have made precipitation retrievals more reliable and are particularly successful over oceans. Retrievals over land are more approximate, since coasts and complex terrain increase uncertainty, and the accuracy of current algorithms deteriorates poleward of $50^{\circ}$. The latter is because these algorithms are tuned to lower-latitude conditions and because they cannot identify precipitation over snowy/icy surfaces.

Combined-satellite algorithms have been developed to merge individual estimates, either as relatively coarse-resolution, long-period climate data records [the Global Precipitation Climatology Project (GPCP) monthly dataset on a $2.5^{\circ} \times 2.5^{\circ}$ latitude/longitude grid begins in 1979; Adler et al. 2003] or, alternatively, as high-resolution precipitation products that start with the launch of the Tropical Rainfall Measuring Mission (TRMM) in late 1997 and have been continued with the successful launch of the Global Precipitation Measurement (GPM) mission in February 2014. A recently released high-resolution dataset covers a somewhat longer period (Funk et al. 2014). Some products use rain gauge data, where available, as input and to calibrate satellite-based rainfall estimates (Huffman et al. 2007). Therefore, satellite-derived products are not all independent of in situ data, and trends based on the satellite record may be affected by inhomogeneities in both the satellite and surface data used (Maidment et al. 2014).

The satellite record has been very useful for understanding precipitation changes. A study sampling blended satellite observations of the wet and dry regimes as they shift spatially from year to year indicates enhanced seasonality (Chou et al. 2013), while Liu and Allan (2013) found tropical ocean precipitation increased by $1.7 \%$ decade $^{-1}$ for the wettest $30 \%$ of the tropics in GPCP data, with declines over the remaining, drier regions of $-3.4 \%$ decade $^{-1}$ for $1988-2008$. Polson et al. (2013a) detected the fingerprint of a strengthening contrast of wet and dry regions in the GPCP satellite record since 1988 and attributed this change largely to greenhouse gas increases. Marvel and Bonfils (2013) arrive at a similar conclusion, explicitly accounting for circulation changes and using the full record. Some of the changes detected in observations were significantly larger than modeled, for example, in wet regions over ocean (Polson et al. 2013a; see also Chou et al. 2013; Liu and Allan 2013).

Atmospheric reanalyses provide a global threedimensional and multidecadal representation of changes in atmospheric circulation, fluxes, and water vapor by assimilating observations (satellite, in situ, radiosondes, etc.) into numerical weather prediction models. Notably, global quasi-observed $P-E$ estimates are available only from reanalyses. Reanalyses, however, are affected by biases in the models and 
by long-term inhomogeneity of the observations, particularly changing input data streams (Trenberth et al. 2005, 2011; Dee et al. 2011; Allan et al. 2014). These factors lead to inconsistencies between reanalyses and substantial uncertainties in their long-term trends: uncertainties that can be explored by using water budget closure constraints (e.g., Trenberth and Fasullo 2013a,b). The issues of long-term homogeneity will be improved in future developments [e.g., European Reanalysis of Global Climate Observations (ERA-CLIM); www.era-clim.eu].

In conclusion, the satellite record is essential for monitoring the changing water cycle on a near-global scale, while future climate quality reanalyses hold considerable promise. Uncertainty estimates on long-term trends are difficult to provide (see online supplement) but would be very useful.

INTERPRETING CHANGES OVER OCEAN. Changes in $P-E$ and precipitation by climate models are particularly consistent over the oceans (Fig. 1b; Meehl et al. 2007; Bony et al. 2013). In terms of observations, in addition to the satellite record, limited in situ records are available, such as evaporation analyses (although fraught with discontinuities and global lack of closure) (Yu and Weller 2007; Yu et al. 2008) and precipitation from island stations and buoys [e.g., Climatic Research Unit (CRU) precipitation data as used in Josey and Marsh (2005)]. Overall, however, the in situ observations lack the spatial and temporal coverage needed to measure global changes [see Xie and Arkin (1998) for precipitation], and satellite and reanalysis data are consequently indispensable.

Both evaporation and precipitation affect local sea surface salinity. Thus, patterns and changes in the net freshwater flux, $P-E$, contribute to its temporal variations, and long-term changes to ocean salinity provide an important independent measurement from which the water cycle can be monitored. It should be noted, however, that in situ ocean salinity is strongly influenced by changes to the ocean's circulation (which is influenced by ocean warming and surface wind changes) and thus care must be taken when using in situ salinity to infer $P-E$ (Durack and Wijffels 2010; Skliris et al. 2014).

Ocean salinity observations have been made since the late nineteenth century by research cruises. Historical observational coverage is, however, sparse in the early part of the record, with near-global coverage achieved only recently (Fig. S1), largely because of the Argo network of 3600 free-drifting floats initiated in 1999 (Freeland et al. 2010). These floats measure the salinity and temperature of the upper $2000 \mathrm{~m}$ of the global ocean almost in real time. The Aquarius and Soil Moisture Ocean Salinity (SMOS) satellite missions have provided global estimates of ocean surface salinity since late 2009 and June 2011, respectively.

The observed pattern of salinity change at high latitudes and in the subtropics is broadly consistent with the expected changes in $P-E$, although the observational uncertainty is also clear (Fig. 3). These observed changes, roughly, reflect an amplification of the climatological pattern of salinity-with salty regions getting saltier and fresh regions getting fresher (Durack et al. 2012; Skliris et al. 2014). Observed salinity changes in the Atlantic and Pacific Oceans since the mid-twentieth century have been found to be outside the range of internal climate variability in model simulations and have been attributed to anthropogenic influences (e.g., Stott et al. 2008; Terray et al. 2012; Pierce et al. 2012). The attribution of salinity changes to anthropogenic factors was important evidence for the Intergovernmental Panel on Climate Change (IPCC)'s conclusion that there has been "likely" a human contribution to the changing water cycle (see Bindoff et al. 2013). However, further work is required to better understand the effects of unforced variability on ocean salinity and their influence on the patterns of reported long-term changes.

It is essential that satellite-based, ship-based, and Argo float measurements continue to monitor the ocean. Reliance on a single record type would hamper the identification of errors introduced by changes in coverage and measurement methods.

\section{INTERPRETING CHANGES OVER LAND.}

Over land, in situ data provide a long-term record of changing humidity and precipitation. However, the lack of reliable homogeneous terrestrial evapotranspiration data hampers studies of changes in the terrestrial water balance. Flux towers provide direct measurements of water, energy, and carbon fluxes at a few points, but only for short periods (typically 5-15 years; e.g., Blyth et al. 2010). Pan evaporation can easily be diagnosed from general circulation climate models (as "potential evaporation") and effectively measures evaporative demand, which is very relevant to some crops and natural ecosystems. Long time series would therefore be valuable (e.g., Greve et al. 2014), but measurements are sparse, and as it is not part of the actual energy or moisture budget, it cannot be deduced from other measurements. Pan evaporation has decreased in many regions studied (related, at least partly, to wind stilling; McVicar et al. 2012), in contrast to actual evapotranspiration measured at Fluxnet sites, which increased until recently 

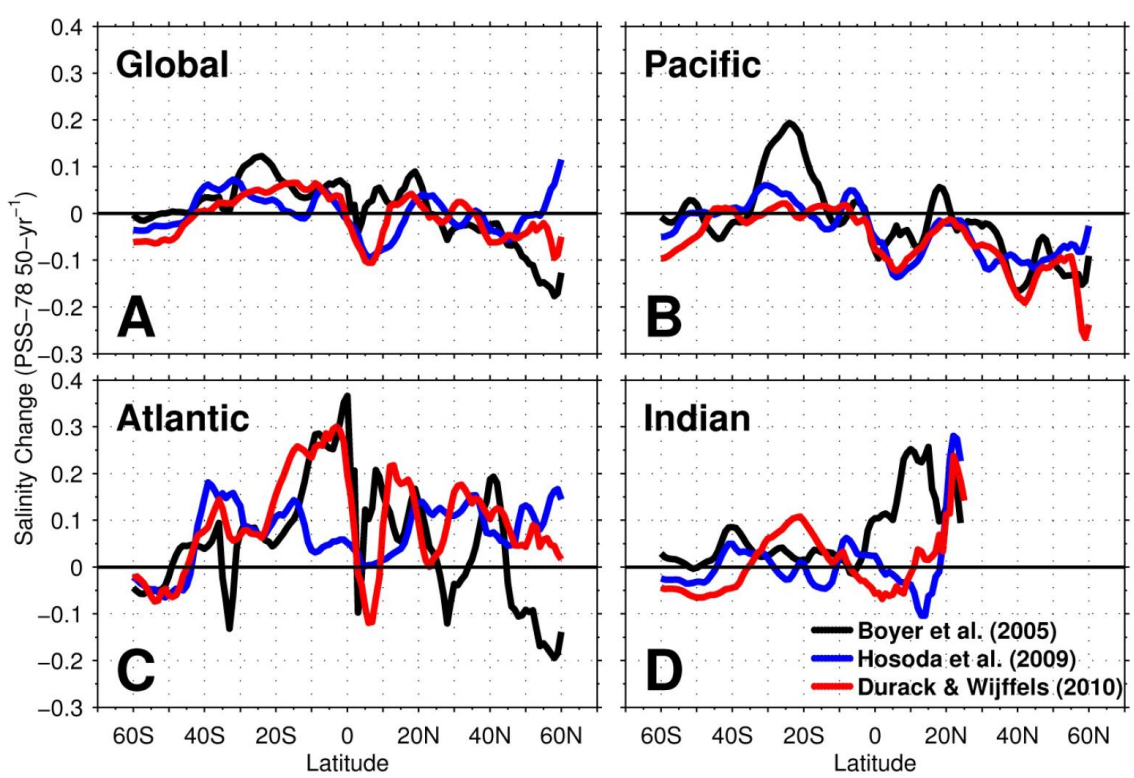

FIG. 3. Three observed estimates of long-term global and basin zonal-mean near-surface salinity changes, nominally for the 1950-2000 period. Positive values show increased salinities and negative values freshening. Changes are expressed on the practical salinity scale (PSS-78) per 50 yr. The data coverage, as used in Durack and Wijffels (20I0), is shown in Fig. SI. Reproduced from Durack et al. (20I3).

(Hartmann et al. 2013). Inferring evaporation from the atmospheric moisture budget in reanalyses (Trenberth et al. 2011; Trenberth and Fasullo 2013b) is the most realistic option to analyze large-scale changes in $P-E$ over land. As was mentioned above, however, reanalyses are affected by model error and their trends by changing data streams, and thus reanalysis evaporation data should be treated with caution.

The most widely used record of the changing water cycle over land is from long-term precipitation station data (e.g., Peterson and Vose 1997; Menne et al. 2012). Several gridded products are available (see Table S1; Harris et al. 2014; Becker et al. 2013; Zhang et al. 2007), of which this paper shows three that have been processed differently, some completely interpolating precipitation over land [Global Precipitation Climatology Centre (GPCC; Becker et al. 2013); CRU (Harris et al. 2014); with information on support available] or only providing values where long-term stations are available (Zhang et al. 2007). An additional dataset [Variability Analysis of Surface Climate Observations (VASClimO); Beck et al. 2005] uses a subset of GPCC stations that are considered long term and homogeneous. Figure 4 shows the density of the station network used in the CRU dataset; Fig. S2 shows the density for GPCC. Generally, data availability increased until 1990 but has dropped since, especially in the tropics. For the GPCC this dramatic drop occurs a decade later.
Country-specific readiness to share data is the biggest constraint for data density in the most recent decade.

The gridded precipitation datasets available vary also in their methods of quality control and homogenization (see online supplemental information). This diversity leads to substantial differences in trends and discrepancies between datasets and contributes to uncertainty in how drought has changed (Trenberth et al. 2014).

Figure 5 illustrates similarities and differences in precipitation change from these datasets for high latitudes, and Fig. 2, upper panel, shows similarities and differences for zonalmean changes. The zonalmean increase in the northern high latitudes shown by most datasets (with the exception of the GPCC full data V6 dataset, which was not constructed with long-term homogeneity as a priority) agrees with the expectation (see Fig. 2, lower panel) and is supported by Arctic regional studies (Rawlins et al. 2010). Min et al. (2008) detected the response to anthropogenic forcing in the observed moistening of northern high latitudes, using the Zhang et al. (2007) dataset. Figure 5, however, suggests substantial observational uncertainty, which may be partly due to coverage and data processing and may contain a small contribution by changing the liquid-to-solid ratio of precipitation (see discussion in supplement).

A substantial fraction of the differences between zonal changes recorded in different datasets can be explained by differences in spatial coverage (Polson et al. 2013b). The IPCC Fifth Assessment report concluded that there is "medium" confidence in precipitation change averaged over land after 1951 (and lower confidence before 1951) because of the data uncertainty (Hartmann et al. 2013). Simulated changes in land precipitation are also uncertain, as evident from Fig. 1 (right panel).

The incomplete spatial coverage of precipitation changes in observations tends to increase noise and hence delay detection of global and large-scale changes (e.g., for precipitation changes; Balan Sarojini 


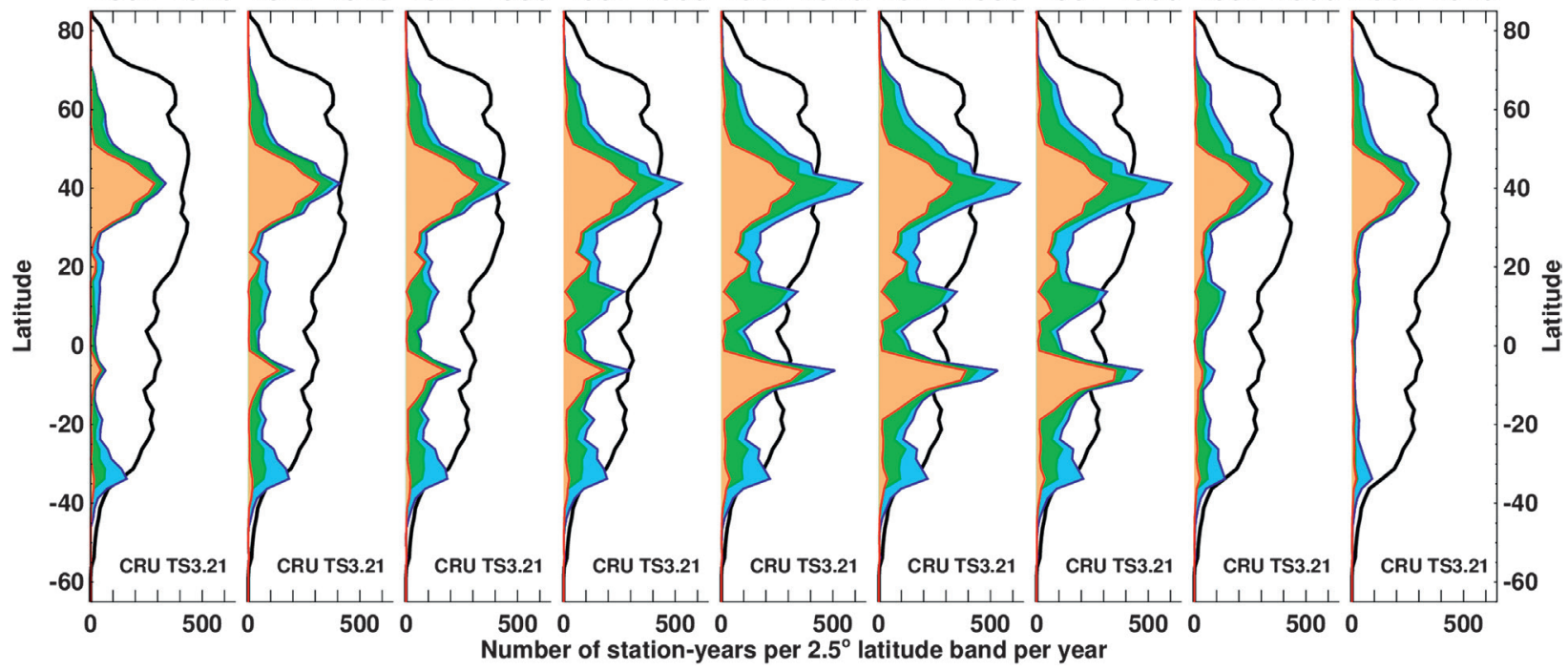

FIG. 4. Number of in situ stations over time for the CRU TS 3.2I gridded precipitation dataset (updated from Harris et al. 2014). Evolution over decades of the latitudinal density of stations per zonal band for the Americas (orange), Europe/Africa (green), and Asia/Australasia (blue), stacked to indicate the zonal total. Incomplete data series are included as a fraction of available data. The black line indicates the number of stations per zonal band required to obtain an average zonal coverage of I station per $(100 \mathrm{~km})^{2}$ of land at that latitude. Thus, absolute station numbers can be seen (shading) in relation to the latitudinally varying land area (black line). Other datasets have similar differences in coverage over time (see Fig. S2 for GPCC).

et al. 2012; Trenberth et al. 2014) (note that in detection and attribution, only regions covered by observed data are analyzed in both models and observations). Since station-based records are point measurements and precipitation tends to be highly variable spatially (e.g., Osborn 1997), many stations are required to correctly reflect large-scale precipitation trends (e.g., Wan et al. 2013). In general, the variability in grid cells based on few stations is higher than if a larger number of stations are used and changes may be recorded incompletely (see Zhang et al. 2007).

Despite these difficulties, zonal-mean precipitation changes agree better with the expected response to forcing than expected by chance and show detectable changes for boreal winter and spring data (Polson et al. 2013b) as well as for annual data (see Fig. 2; Zhang et al. 2007; Polson et al. 2013b) for most datasets. These findings contributed to the IPCC Fifth Assessment's conclusion of "medium confidence" that a human influence on global-scale land precipitation change is emerging (Bindoff et al. 2013). Wu et al. (2013) argue that the lack of an increase in NH land precipitation over the last century is because aerosols induce a reduction in precipitation that counteracts the increase in precipitation expected from increases in greenhouse gases.

Because of the data uncertainty, it is currently difficult to decide whether observed precipitation changes are larger than model-simulated changes (Polson et al. 2013b). Averaging across mislocated precipitation features in models may reduce the magnitude of multimodel mean-simulated precipitation change. This bias can be reduced by identifying fingerprints that track precipitation features rather than geographical patterns (Liu and Allan 2013; Polson et al. 2013a; Marvel and Bonfils 2013) or by morphing model changes onto observed features (A. A. L. Levy et al. 2013). However, in some cases, results still show observed changes that are large compared to model simulations (e.g., Polson et al. 2013a,b).

In summary, the record over land is extensive in time but has serious limitations in spatial coverage and homogeneity. The drop in availability of recent in situ precipitation data (Figs. 4, S2) is of real concern. Data are particularly sparse in the tropics and subtropics, where substantial and spatially variable changes with pronounced spatial structure are expected. In addition to improving gauge density, more data-rescue funding and improved data-sharing practices and capabilities would help to address this problem.

\section{INTENSIFICATION OF PRECIPITATION}

EXTREMES. Since storms are fueled by moisture convergence, storm-related extremes are expected to increase in a moister atmosphere (Emanuel 1999; Trenberth et al. 2003). It is less clear how large this 

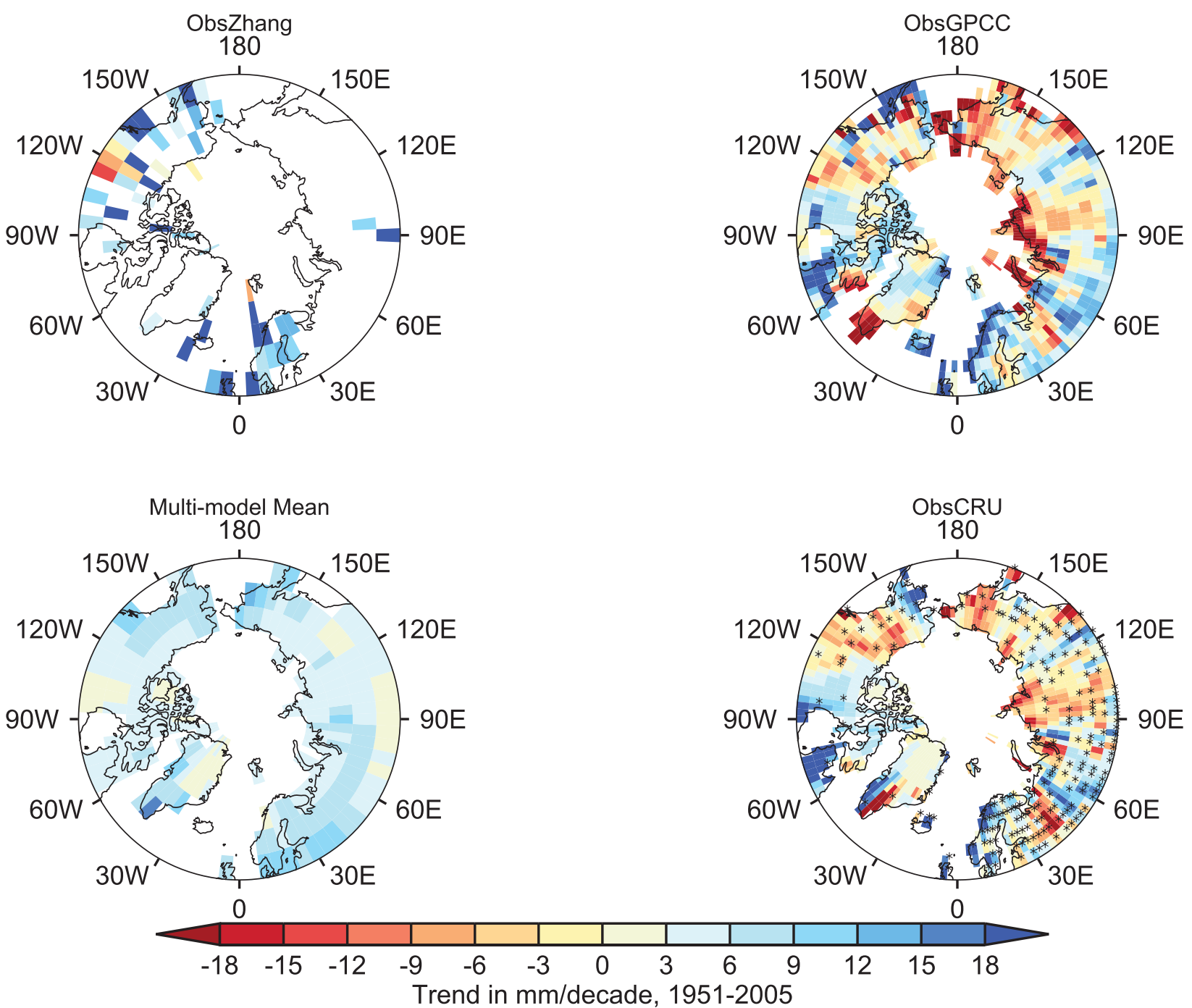

Fig. 5. High-latitude $\left(55^{\circ}-90^{\circ} \mathrm{N}\right)$ annual-mean precipitation trends (mm decade $\left.{ }^{-1}\right)$ from $195 \mathrm{I}$ to 2005 for three observational datasets, Zhang et al. (2007; updated; $5^{\circ} \times 5^{\circ}$ grid), GPCC full data V6 (Becker et al. 2013), and CRU, updated (Harris et al. 2014; grid points with CRU station data available for $>95 \%$ of the time are stippled), compared to the CMIP5 multimodel-mean trend of historical runs with all external forcings (multimodel mean). Note that both GPCC and CRU use spatial interpolation to varying extents, while Zhang et al. (2007) average a subset of stations only, considered to be homogeneous in the long term within grid boxes.

increase will be, as limited moisture availability over land and possible stabilization of atmospheric temperature profiles tend to reduce the empirically derived response in precipitation extremes below the Clausius-Clapeyron-based increase in water vapor of $6 \%-7 \% \mathrm{~K}^{-1}$, while feedbacks of increased latent heat release on storm intensity may amplify the response for subdaily precipitation extremes (Lenderink and van Meijgaard 2008; Berg et al. 2013; Westra et al. 2014). Overall, under global warming, a substantial increase in the intensity of the stronger storms and precipitation events is expected. This increase is expected to be larger for more intense events (see Allen and Ingram 2002; Pall et al. 2011; Kharin et al. 2013; Field et al. 2012) and is a robust fingerprint for the detection of climate change (Hegerl et al. 2004).
This larger increase in intense precipitation than annual total precipitation implies light or no rain must become more common, suggesting longer dry spells and increased risk of drought, exacerbated by increased potential evapotranspiration (Trenberth et al. 2003). How this intensification of extremes of the water cycle will be expressed is uncertain, as climate models still struggle to properly depict the diurnal cycle, frequency, intensity, and type of precipitation (see Flato et al.2013), a problem that may be improved in part with the use of higher resolutions (e.g., Kendon et al. 2012; Strachan et al. 2013; Demory et al. 2014; Arakawa and Jung 2011). Accurate representation of local storm dynamics may be an essential requirement for predicting changes to convective extremes (Kendon et al. 2014). 
Worldwide in situ data for analyzing changes in daily precipitation extremes have been collected by the CLIVAR Expert Team on Climate Change Detection and Indices (Donat et al. 2013). However, the record is far from complete in covering the global landmasses and is particularly sparse in key tropical regions. Increases in precipitation intensity have been identified in observations over many land regions (Fowler and Kilsby 2003; Groisman et al. 2005; Min et al. 2011; Zolina et al. 2010). Analysis of observed annual maximum 1-day precipitation over land areas with sufficient data samples indicates an increase with global-mean temperature of about $6 \%-8 \% \mathrm{~K}^{-1}$ (Westra et al. 2013). Min et al. (2011) and Zhang et al. (2013) report detection of human influence on widespread intensification of extreme precipitation over $\mathrm{NH}$ land, although with substantial uncertainty in data and estimates of internal variability. Observed responses of daily precipitation extremes to interannual variability (e.g., Liu and Allan 2012; see also Kenyon and Hegerl 2010) potentially offer a constraint on climate change projections for future changes in extremes (O'Gorman 2012).

Characterizing subdaily precipitation variability is difficult on large scales, given the limitations of the satellite record (see above), and agreement is poorer on short time scales than for multiday averages (Liu and Allan 2012). However, a number of regional studies show recent increasing subdaily precipitation intensities in response to rising temperatures (e.g., Lenderink and van Meijgaard 2008; Utsumi et al. 2011; Westra et al. 2014). In the future, radar data exchanged globally show promise, if remaining technical and administrative problems can be resolved (e.g., Winterrath et al. 2012a,b; Michelson et al. 2013; Berg et al. 2013).

In short, it is essential to observe precipitation extremes to understand changing precipitation characteristics and quantify human-induced changes. However, uncertainties are substantial, and temporal and spatial scales reliably observable at present fall short of what is necessary for characterizing global changes.

\section{THE CHALLENGE OF CLIMATE VARIABIL-}

ITY. Natural variability generated within the climate system can cause multidecadal features in precipitation that are difficult to separate from the response to long-term forcing, especially in view of the relatively short observational record (e.g., Dai 2013b). When determining if an observed change is significant relative to climate variability, a large sample of variability realizations from climate model simulations is generally used, since the observed record is short. However, discrepancies between simulated precipitation variability and that estimated from observations are substantial, particularly in the tropics (Zhang et al. 2007; see supplement) because of a combination of observational and model limitations. This introduces substantial uncertainty in detection and attribution results, even when model estimates of variance are doubled (as is often done; e.g., Zhang et al. 2007; Polson et al. 2013b). Long-term observed data obtained, for example, through data rescue are critical when evaluating simulations of multidecadal variability (www.oldweather.org; www.met-acre.org; Allan et al. 2011).

Figure 6 illustrates how natural modes can induce apparent trends in precipitation over large regions (after Dai 2013b). The interdecadal Pacific oscillation index (IPO; closely related to the Pacific decadal oscillation; Liu 2012), for example, corresponds to an index of Southwest U.S. precipitation in observations and model experiments forced by sea surface temperatures (e.g., Schubert et al. 2009). This suggests that both an increase in Southwest U.S. precipitation from the late 1940s to early 1980s and a subsequent decrease are largely caused by internal variability. El Niño and the IPO also influence precipitation patterns globally (Gu and Adler 2013; Dai 2013b), which can influence trends over short periods such as those from satellites (Polson et al. 2013a; Liu and Allan 2013). This strong climate variability makes it difficult to detect the expected long-term regional precipitation response to greenhouse gas forcing using historical data (see also Deser et al. 2012).

For understanding and attributing changes in the water cycle, it is therefore important to account carefully for natural decadal climate variability, be it internally generated or volcanically forced. This is particularly true when using short records. Because unforced internal variability is realization dependent, discrepancies between model-based and observed records of variability should be expected and need to be accounted for in comparing models with observations for climatology, variability, and trends.

\section{CONCLUSIONSAND RECOMMENDATIONS.}

There is strong evidence that changes are underway in aspects of the water cycle, which are consistent with theoretical expectations of the hydrological response to increased greenhouse gases and a warming planet. Many aspects of water cycle change, however, remain uncertain owing to small expected signals relative to the noise of natural variability, limitations of climate models, and short and inhomogeneous observational datasets. 


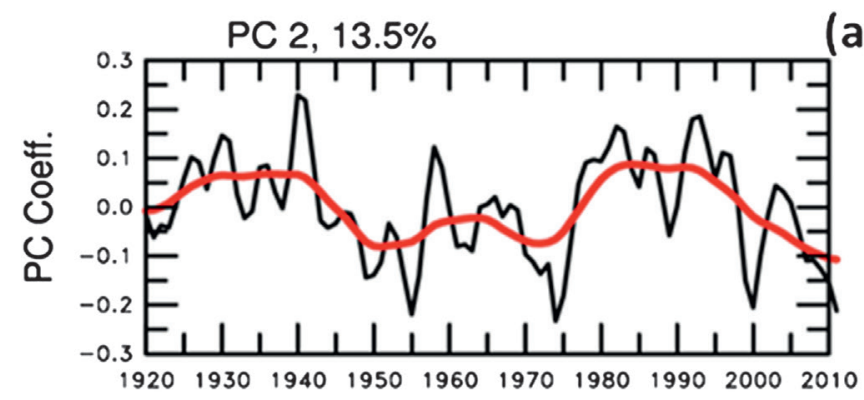

(a)
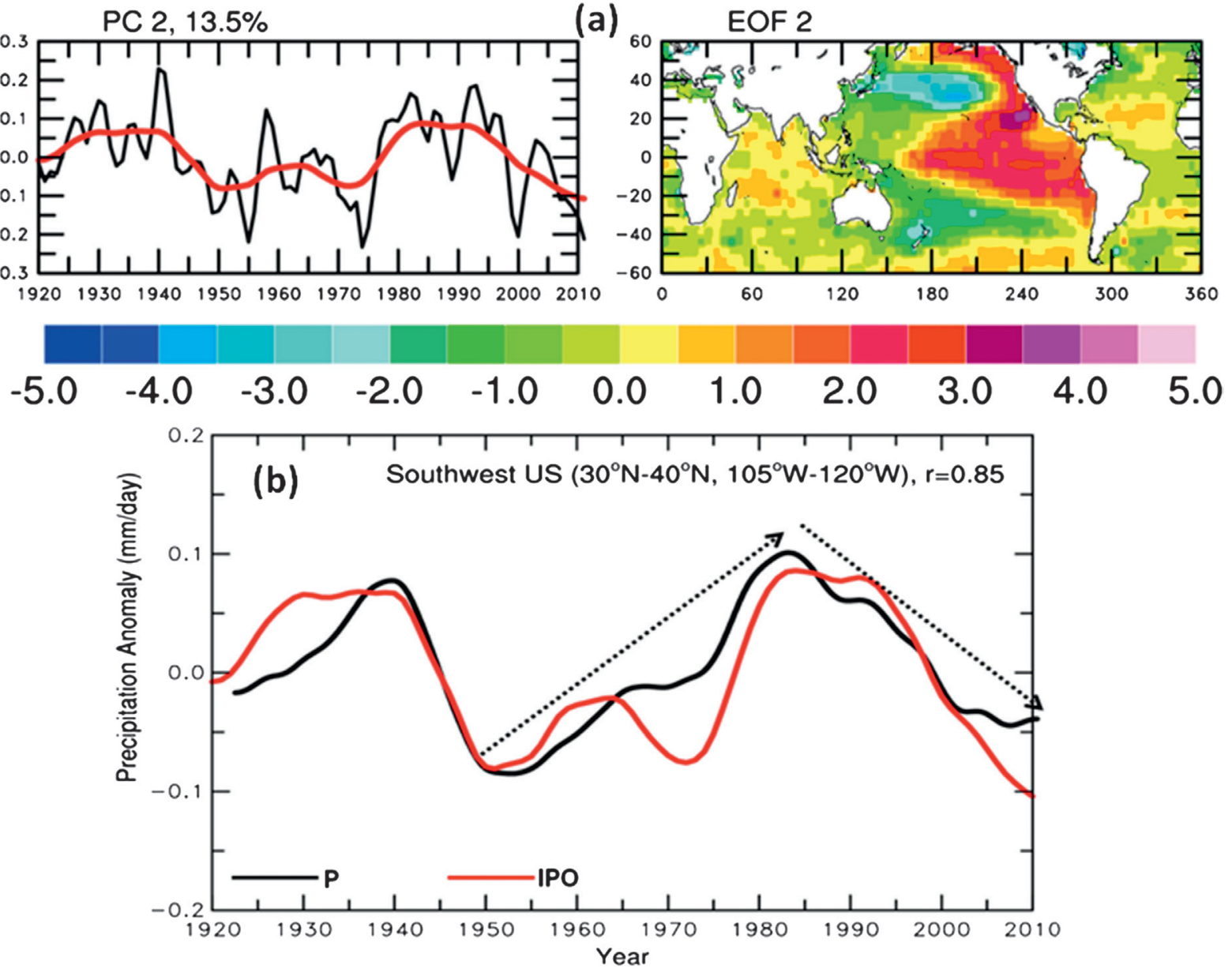

FIG. 6. (top) The second EOF of global sea surface temperature (3-yr running mean) data from I920 to $201 \mathrm{I}$ based on the HadISST dataset. The red line is a smoothed index representing the IPO. (bottom) Smoothed precipitation anomalies averaged over the Southwest United States (black line) compared with the IPO index, scaled for comparison. (Reproduced from Dai 20I3b.)

Uncertainty may be reduced by cross-validating changes between multiple datasets and across variables by putting these comparisons in the context of the theoretical expectation of the response of the water cycle to global climate change and by exploring closure constraints. The observations, for example, suggest increases in high-latitude precipitation, global-scale atmospheric humidity, and precipitation extremes that are consistent with expected changes. Furthermore, satellite data show signals of precipitation increases over wet regions and decreases over dry regions, corroborated by in situ data over land and physically consistent with an amplification of salinity patterns over the global ocean. The consistency in the evidence of changes of precipitation over land and from changes in ocean salinity is reflected in the IPCC's conclusion that human activity has likely influenced the global water cycle since 1960 (Bindoff et al. 2013), even though confidence in individual lines of evidence, such as attribution of precipitation changes to causes, is lower.

Observational uncertainty and a low signal-tonoise ratio pose serious difficulties when determining the magnitude of the human contribution to observed changes. Several studies report observed changes that are significantly larger than those simulated by climate models. However, these findings were generally not robust to data uncertainty. The uncertainty arises because the satellite record is short compared to decadal climate variability, and affected by calibration uncertainty, and because the available in situ record has many gaps, particularly in the tropics and subtropics and is sparse on subdaily time scales. Thus, while observations can place constraints on future temperature changes, this is not yet possible for future precipitation projections (see Collins et al. 2013; Bindoff et al. 2013).

To improve the situation, we recommend the following: 
1) The satellite record is vital, particularly to capture the strong changes over ocean that are robustly predicted by models. Only the full constellation can capture the intermittent nature of precipitation and capture extremes. The new GPM mission has exciting prospects for better calibration of space-based observations. Improved sampling by the constellation should enable the intermittency of precipitation to be better handled. Planning for future missions and providing continuity and temporal overlap of measurements is essential to be able to reliably determine long-term trends.

2) In situ stations are vital both for crossvalidating and calibrating satellite datasets and for long-term monitoring. However, the drop in available in situ data in recent decades, as illustrated for precipitation (Fig. 4), is alarming and needs to be addressed. Many observations are not made available for analysis, while some remain in paper form only and are not catalogued. It is necessary to strengthen efforts to rescue, scan, and digitize data. Also, impediments to data sharing need to be overcome, and data delivery needs to be more timely in order to monitor the changing water cycle in nearreal time, as is done for temperature.

3) There is need for better global coverage and higher time resolution data to capture changing precipitation extremes. Hourly datasets are needed to track and identify changes in short-term extremes, which are another important fingerprint of anthropogenic changes and critical for flood management.

4) Gridded products of in situ precipitation change show substantial differences (Figs. 2,5 ), related to numbers of stations used, their homogeneity, manner of analysis, quality control procedures, and treatment of changing data coverage over time. This uncertainty needs to be better characterized and best practices developed.

5) Observations in key regions are still sparse, particularly in the tropics, where the observing system is insufficient to record the anticipated changes in the water cycle. For the Asian monsoon, data sparsity is partly related to practical and administrative issues with data sharing. An improved international capacity to monitor all aspects of observed changes is important.
6) Ocean salinity observations provide an independent insight into the changing water cycle. Continued maintenance and improved coverage of the Argo program, along with the development of satellite missions to follow Aquarius/SMOS for ocean salinity will strongly improve our understanding of global water cycle changes.

7) Key diagnostics, such as $P-E$, are not directly observable on large scales. Therefore, reanalysis data are vital, and their homogeneity in time and reliability for the study of long-term changes need to be improved. Climate quality reanalysis will be very useful and is strongly encouraged. Closure of the water cycle using multiple variables provides a physical constraint that should be exploited to help quantify uncertainties.

8) Analyses of observed changes are more powerful if they make use of and diagnose physical mechanisms that are responsible for the atmospheric and oceanic change patterns. Studies need to investigate the robustness of results across data products and evaluate the physical consistency of recorded changes across water cycle variables. Process studies may be able to constrain and better understand the fast circulation response to $\mathrm{CO}_{2}$ forcing, which is a source of uncertainty.

9) Uncertainty in the role of aerosols on precipitation is central when quantifying the human contribution to observed changes. Aerosols vary enormously in space and time and in composition. Covariability with water vapor and clouds remains an issue. Interactions between aerosol and cloud microphysics need to be better understood and represented in models, and the role of aerosol on precipitation changes needs to be better understood. This requires scientists from aerosol and water cycle communities to work together.

10) Variability generated within the climate system, particularly regionally on interannual to multidecadal time scales, has a large effect on water cycle variables and delays detection and emergence of changes. There is substantial uncertainty in present understanding of the magnitude and structure of variability in the water cycle that, if addressed, will improve the reliability of detection and attribution 
studies and help societies in managing the impacts of decadal variability and change.

ACKNOWLEDGMENTS. We thank several anonymous reviewers for their helpful and perceptive suggestions. The workshop that formed the basis for this paper was funded by the U.K. Natural Environment Research Council (NERC Grant NE/I006672/1). We thank Eleanor Blyth and David Parker for comments. Robin Chadwick, Kate Willett, William Ingram, Lizzie Kendon, and Peter Stott were supported by the Joint DECC/Defra Met Office Hadley Centre Climate Programme (GA01101). Paul Durack is supported by the Lawrence Livermore National Laboratory that is funded by the U.S. Department of Energy under Contract DE-AC5207NA27344, and William Ingram is partly supported by NERC Grant NE/I00680X/1. Gabi Hegerl and Richard Allan are partly supported by NCAS. Kevin Trenberth is supported by NASA Grant NNX11AG69G. P. L. Vidale, R. P. Allan, B. Balan Sarojini, C. Liu, E. Black, P. Stott, G. Hegerl, D. Polson, R. Marsh, N. Skliris, and Laura Wilcox are supported by the PAGODA project of the Changing Water Cycle programme of NERC under Grant NE/I006672/1. G. Hegerl and D. Polson are supported by the ERC Grant EC320691. A. Dai acknowledges the support of NSF Grant AGS-1353740. H. J. Fowler and G. Hegerl are funded by the Wolfson Foundation and the Royal Society as Royal Society Wolfson Research Merit Award (WM140025 and WM130060, respectively) holders. G. Hegerl is further supported by the European Research Council (TITAN, ERC-2012-AdG 320691). H. J. Fowler is supported by the CONVEX project of the Changing Water Cycle programme of NERC under Grant NE/I006680/1 and European Research Council funded INTENSE (ERC-2013-CoG).

\section{REFERENCES}

Ackerley, D., B. B. B. Booth, S. H. E. Knight, E. J. Highwood, D. J. Frame, M. R. Allen, and D. P. Rowell, 2011: Sensitivity of twentieth-century Sahel rainfall to sulfate aerosol and $\mathrm{CO}_{2}$ forcing. J. Climate, 24, 4999-5014, doi:10.1175/JCLI-D-11-00019.1.

Adler, R. F., and Coauthors, 2003: The Version 2 Global Precipitation Climatology Project (GPCP) monthly precipitation analysis (1979-present). $J$. Hydrometeor., 4, 1147-1167, doi:10.1175/1525 -7541(2003)004<1147:TVGPCP>2.0.CO;2.

Allan, R., P. Brohan, G. P. Compo, R. Stone, J. Luterbacher, and S. Bronnimann, 2011: The International Atmospheric Circulation Reconstructions over the Earth (ACRE) initiative. Bull. Amer. Meteor. Soc., 92, 1421-1425, doi:10.1175/2011BAMS3218.1

Allan, R. P., 2012: Regime dependent changes in global precipitation. Climate Dyn., 39, 827-840, doi:10.1007 /s00382-011-1134-x.
- 2014: Dichotomy of drought and deluge. Nat. Geosci., 7, 700-701, doi:10.1038/ngeo2243.

-, C. Liu, M. Zahn, D. A. Lavers, E. Koukouvagias, and A. Bodas-Salcedo, 2014: Physically consistent responses of the global atmospheric hydrological cycle in models and observations. Surv. Geophys., 35, 533-552, doi:10.1007/s10712-012-9213-z.

Allen, M. R., and W. J. Ingram, 2002: Constraints on future changes in climate and the hydrologic cycle. Nature, 419, 224-232, doi:10.1038/nature01092.

Allen, R. J., S. C. Sherwood, J. R. Norris, and C. S. Zender, 2012: Recent Northern Hemisphere tropical expansion primarily driven by black carbon and tropospheric ozone. Nature, 485, 350-355, doi:10.1038 /nature11097.

Arakawa, A., and J.-H. Jung, 2011: Multiscale modeling of the moist convective atmosphere: A review. Atmos. Res., 102, 263-285, doi:10.1016/j .atmosres.2011.08.009.

Arnell, N. W., and Coauthors, 2013: A global assessment of the effects of climate policy on the impacts of climate change. Nat. Climate Change, 3, 512-519, doi:10.1038/nclimate1793.

Balan Sarojini, B., P. A. Stott, E. Black, and D. Polson, 2012: Fingerprints of changes in annual and seasonal precipitation from CMIP5 models over land and ocean. Geophys. Res. Lett., 39, L21706, doi:10.1029/2012GL053373.

Beck, C., J. Grieser, and B. Rudolf, 2005: A new monthly precipitation climatology for the global land areas for the period 1951 to 2000. Climate Status Rep. 2004, 181-190. [Available online at www.dwd.de/bvbw /generator/DWDWWW/Content/Oeffentlichkeit /KU/KU4/KU42/en/VASClimO/pdf_28__precipit ation,templateId=raw, property=publicationFile.pdf /pdf_28_precipitation.pdf.]

Becker, A., P. Finger, A. Meyer-Christoffer, B. Rudolf, K. Schamm, U. Schneider, and M. Ziese, 2013: A description of the global land-surface precipitation data products of the Global Precipitation Climatology Centre with sample applications including centennial (trend) analysis from 1901-present. Earth Syst. Sci. Data Discuss., 5, 71-99, doi:10.5194/essd-5-71-201.

Bengtsson, L., K. I. Hodges, S. Koumoutsaris, M. Zahn, and N. Keenlyside, 2011: The changing atmospheric water cycle in polar regions in a warmer climate. Tellus, 63A, 907-920, doi:10.1111/j.1600-0870.2011.00534.x.

Berg, P., C. Moseley, and J. O. Haerter, 2013: Strong increase in convective precipitation response to higher temperatures. Nat. Geosci., 6, 181-185, doi:10.1038/ngeo1731.

Berry, D. I., and E. C. Kent, 2009: A new air-sea interaction gridded dataset from ICOADS with uncertainty estimates. Bull. Amer. Meteor. Soc., 90, 645-656, doi:10.1175/2008BAMS2639.1. 
—, and — 2011: Air-sea fluxes from ICOADS: The construction of a new gridded dataset with uncertainty estimates. Int. J. Climatol., 31, 987-1001, doi:10.1002/joc.2059.

Bindoff, N., and Coauthors, 2013: Detection and attribution of climate change: From global to regional. Climate Change 2013: The Physical Science Basis, T. F. Stocker et al., Eds., Cambridge University Press, 867-952.

Bintanja, R., and F. Selten, 2014: Future increases in Arctic precipitation linked to local evaporation and sea-ice retreat. Nature, 509, 479-482, doi:10.1038/nature13259.

Blyth, E. M., D. B. Clark, R. Ellis, C. Huntingford, S. Los, M. Pryor, M. Best, and S. Sitch, 2010: A comprehensive set of benchmark tests for a land surface model of simultaneous fluxes of water and carbon at both the global and seasonal scale. Geosci. Model Dev., 3, 1829-1859, doi:10.5194/gmdd-3-1829-2010.

Bony, B., G. Bellon, D. Klocke, S. Sherwood, S. Fermepin, and S. Denvil, 2013: Robust direct effect of carbon dioxide on tropical circulation and regional precipitation. Nat. Geosci., 6, 447-451, doi:10.1038/ngeo1799.

Chadwick, R. S., I. A. Boutle, and G. Martin, 2013: Spatial patterns of precipitation change in CMIP5: Why the rich do not get richer in the tropics. J. Climate, 26, 3803-3822, doi:10.1175/JCLI-D-12-00543.1.

Chang, C. Y., J. C. H. Chiang, M. F. Wehner, A. R. Friedman, and R. Ruedy, 2011: Sulfate aerosol control of tropical Atlantic climate over the twentieth century. J. Climate, 24, 2540-2555, doi:10.1175/2010JCLI4065.1.

Chou, C., J. D. Neelin, C. A. Chen, and J. Y. Tu, 2009: Evaluating the "rich-get-richer" mechanism in tropical precipitation change under global warming. J. Climate, 22, 1982-2005, doi:10.1175/2008JCLI2471.1.

— , J. C. H. Chiang, C.-W. Lan, C.-H. Chung, Y.-C. Liao, and C.-J. Lee, 2013: Increase in the range between wet and dry season precipitation. Nat. Geosci., 6, 263-267, doi:10.1038/ngeo1744.

Chung, E.-S., B. Soden, B. J. Sohn, and L. Shi, 2014: Upper-tropospheric moistening in response to anthropogenic warming. Proc. Natl. Acad. Sci. USA, 111, 11 636-11641, doi:10.1073/pnas.1409659111.

Collins, M., and Coauthors, 2013: Long-term climate change: Projections, commitments and irreversibility. Climate Change 2013: The Physical Science Basis, T. F. Stocker et al., Eds., Cambridge University Press, 1029-1136.

Dai, A., 2006: Recent climatology, variability and trends in global surface humidity. J. Climate, 19, 3589-3606, doi:10.1175/JCLI3816.1.

— , 2011a: Drought under global warming: A review. Wiley Interdiscip. Rev.: Climate Change, 2, 45-65, doi:10.1002/wcc.81.
— , 2011b: Characteristics and trends in various forms of the Palmer drought severity index during 1900-2008. J. Geophys. Res., 116, D12115, doi:10.1029/2010JD015541.

_ 2013a: Increasing drought under global warming in observations and models. Nat. Climate Change, 3, 52-58, doi:10.1038/nclimate1633.

— 2013b: The influence of the inter-decadal Pacific Oscillation on U.S. precipitation during 1923-2010. Climate Dyn., 41, 633-646, doi:10.1007 /s00382-012-1446-5.

—, T. Qian, K. E. Trenberth, and J. D. Milliman, 2009: Changes in continental freshwater discharge from 1948-2004. J. Climate, 22, 2773-2791, doi:10.1175/2008JCLI2592.1.

Dee, D. P., and Coauthors, 2011: The ERA-Interim reanalysis: Configuration and performance of the data assimilation system. Quart. J. Roy. Meteor. Soc., 137, 553-597, doi:10.1002/qj.828.

Demory, M.-E., P. L. Vidale, M. J. Roberts, P. Berrisford, J. Strachan, R. Schiemann, and M. S. Mizielinski, 2014: The role of horizontal resolution in simulating drivers of the global hydrological cycle. Climate Dyn., 42, 2201-2225, doi:10.1007/s00382-013-1924-4.

Deser, C., A. S. Phillips, V. Bourdette, and H. Teng, 2012: Uncertainty in climate change projections: The role of internal variability. Climate Dyn., 38, 527-546, doi:10.1007/s00382-010-0977-x.

Donat, M. G., and Coauthors, 2013: Updated analyses of temperature and precipitation extreme indices since the beginning of the twentieth century: The HadEX2 dataset. J. Geophys. Res. Atmos., 118, 2098-2118, doi:10.1002/jgrd.50150.

Dong, B., R. T. Sutton, E. J. Highwood, and L. J. Wilcox, 2014: The impacts of European and Asian anthropogenic sulfur dioxide emissions on Sahel rainfall. J. Climate, 27, 7000-7017, doi:10.1175/JCLI-D-13-00769.1.

Durack, P. J., and S. E. Wijffels, 2010: Fifty-year trends in global ocean salinities and their relationship to broad-scale warming. J. Climate, 23, 4342-4362, doi:10.1175/2010JCLI3377.1.

,-- , and R. J. Matear, 2012: Ocean salinities reveal strong global water cycle intensification during 1950-2000. Science, 336, 455-458, doi:10.1126 /science.1212222.

- - , and T. P. Boyer, 2013: Long-term salinity changes and implications for the global water cycle. Ocean Circulation and Climate-A 21st Century Perspective, G. Siedler et al., Eds., International Geophysics Series, Vol. 103, Elsevier, 727-757, doi:10.1016 /B978-0-12-391851-2.00028-3.

Emanuel, K. A., 1999: Thermodynamic control of hurricane intensity. Nature, 401, 665-669, doi:10.1038/44326. 
Field, C. B., and Coauthors, Eds., 2012: Managing the Risks of Extreme Events and Disasters to Advance Climate Change Adaptation. Cambridge University Press, $582 \mathrm{pp}$.

Flato, G., and Coauthors, 2013: Evaluation of climate models. Climate Change 2013: The Physical Science Basis, T. F. Stocker et al., Eds., Cambridge University Press, 741-866.

Fowler, H. J., and C. G. Kilsby, 2003: Implications of changes in seasonal and annual extreme rainfall. Geophys. Res. Lett., 30, 1720, doi:10.1029/2003GL017327.

Freeland, H., and Coauthors, 2010: Argo-A decade of progress. Proc. OceanObs'09: Sustained Ocean Observations and Information for Society, Vol. 2, ESA Publ. WPP-306, Venice, Italy, ESA, doi:10.5270 /OceanObs09.cwp.32.

Funk, C. C., and Coauthors, 2014: A quasi-global precipitation time series for drought monitoring. U.S. Geological Survey Data Series 832, 4 pp., doi:10.3133 /ds832.

Greve, P., B. Orlowsky, B. Mueller, J. Sheffield, M. Reichstein, and S. I. Seneviratne, 2014: Global assessment of trends in wetting and drying over land. Nat. Geosci., 7, 716-721, doi:10.1038/ngeo2247.

Groisman, P. Ya., R. W. Knight, D. R. Easterling, T. R. Karl, G. C. Hegerl, and V. N. Razuvaev, 2005: Trends in intense precipitation in the climate record. J. Climate, 18, 1326-1350, doi:10.1175/JCLI3339.1.

Gu, G., and R. F. Adler, 2013: Interdecadal variability/ long-term changes in global precipitation patterns during the past three decades: Global warming and/ or Pacific decadal variability? Climate Dyn., 40, 3009-3022, doi:10.1007/s00382-012-1443-8.

$\_, \ldots$, G. J. Huffman, and S. Curtis, 2007: Tropical rainfall variability on interannual-to-interdecadal/ longer-time scales derived from the GPCP monthly product. J. Climate, 20, 4033-4046, doi:10.1175 /JCLI4227.1.

Guo, L., E. J. Highwood, L. C. Shaffrey, and A. G. Turner, 2012: The effect of regional changes in anthropogenic aerosols on rainfall of the East Asian summer monsoon. Atmos. Chem. Phys. Discuss., 12, 23007-23038, doi:10.5194/acpd-12-23007-2012.

Harris, I., P. D. Jones, T. J. Osborn, and D. H. Lister, 2014: Updated high-resolution grids of monthly climatic observations-The CRU TS 3.1 dataset. Int. J. Climatol., 34, 623-642, doi:10.1002/joc.3711.

Hartmann, D., and Coauthors, 2013: Observations: Atmosphere and surface. Climate Change 2013: The Physical Science Basis, T. F. Stocker et al., Eds., Cambridge University Press, 159-254.

Haywood, J. M., A. Jones, N. Bellouin, and D. Stephenson, 2013: Asymmetric forcing from stratospheric aerosols impacts Sahelian rainfall. Nat. Climate Change, 3, 660-665, doi:10.1038/nclimate1857.

Hegerl, G. C., and F. W. Zwiers, 2011: Use of models in detection and attribution of climate change. Wiley Interdiscip. Rev.: Climate Change, 2, 570-591, doi:10.1002/wcc.121.

,$- \ldots$, P. A. Stott, and V. V. Kharin, 2004: Detectability of anthropogenic changes in annual temperature and precipitation extremes. J. Climate, 17, 3683-3700, doi:10.1175/1520-0442(2004)017<3683:DO ACIA > 2.0.CO;2.

Held, I. M., and B. J. Soden, 2006: Robust responses of the hydrological cycle to global warming. J. Climate, 19, 5686-5699, doi:10.1175/JCLI3990.1.

Huffman, G. J., and Coauthors, 2007: The TRMM Multisatellite Precipitation Analysis: Quasi-global, multiyear, combined-sensor precipitation estimates at fine scale. J. Hydrometeor., 8, 38-55, doi:10.1175 /JHM560.1.

Hwang, Y.-T., D. M. W. Frierson, and S. M. Kang, 2013: Anthropogenic sulfate aerosol and the southward shift of tropical precipitation in the late 20th century. Geophys. Res. Lett., 40, 2845-2850, doi:10.1002/grl.50502.

Iles, C., and G. C. Hegerl, 2014: The global precipitation response to volcanic eruptions in the CMIP5 models. Environ. Res. Lett., 9, 104012, doi:10.1088/1748 $-9326 / 9 / 10 / 104012$.

Johns, T. J., and Coauthors, 2011: Climate Change under aggressive mitigation: The ENSEMBLES multimodel experiment. Climate Dyn., 37, 1975-2003, doi:10.1007/s00382-011-1005-5.

Josey, S. A., and R. Marsh, 2005: Surface freshwater flux variability and recent freshening of the North Atlantic in the eastern subpolar gyre. J. Geophys. Res., 110, C05008, doi:10.1029/2004JC002521.

Joshi, M. M., J. M. Gregory, M. J. Webb, D. M. Sexton, and T. C. Johns, 2008: Mechanisms for the land/sea warming contrast exhibited by simulations of climate change. Climate Dyn., 30, 455-465, doi:10.1007 /s00382-007-0306-1.

Kendon, E. J., N. M. Roberts, C. A. Senior, and M. J. Roberts, 2012: Realism of rainfall in a very highresolution regional climate model. J. Climate, 25, 5791-5806, doi:10.1175/JCLI-D-11-00562.1.

,-- , H. J. Fowler, M. J. Roberts, S. C. Chan, and C. A. Senior, 2014: Heavier summer downpours with climate change revealed by weather forecast resolution model. Nat. Climate Change, 4, 570-576, doi:10.1038/nclimate2258.

Kenyon, J., and G. C. Hegerl, 2010: Influence of modes of climate variability on global precipitation extremes. J. Climate, 23, 6248-6262, doi:10.1175/2010JCLI3617.1. 
Kharin, V. V., F. W. Zwiers, X. Zhang, and M. Wehner, 2013: Changes in temperature and precipitation extremes in the CMIP5 ensemble. Climatic Change, 119, 345-357, doi:10.1007/s10584-013-0705-8.

Kidd, C., and G. J. Huffman, 2011: Global precipitation measurement. Meteor. Appl., 18, 334-353, doi:10.1002/met.284.

Kitoh, A., H. Endo, K. Krishna Kumar, I. F. A. Cavalcanti, P. Goswami, and T. Zhou, 2013: Monsoons in a changing world: A regional perspective in a global context. J. Geophys. Res. Atmos., 118, 3053-3065, doi:10.1002/jgrd.50258.

Kundzewicz, Z. W., and Coauthors, 2007: Freshwater resources and their management. Climate Change 2007: Impacts, Adaptation and Vulnerability, M. L. Parry et al., Eds., Cambridge University Press, 173-210.

Lambert, H., and M. Webb, 2008: Dependence of global mean precipitation on surface temperature. Geophys. Res. Lett., 35, L16706, doi:10.1029/2008GL034838.

Lau, K. M., M. K. Kim, and K. M. Kim, 2006: Asian summer monsoon anomalies induced by aerosol direct forcing: The role of the Tibetan Plateau. Climate Dyn., 26, 855-864, doi:10.1007/s00382-006-0114-z.

Lazo, J. K., M. Lawson, P. H. Larsen, and D. M. Waldman, 2011: U.S. economic sensitivity to weather variability. Bull. Amer. Meteor. Soc., 92, 709-720, doi:10.1175/2011BAMS2928.1.

Leibensperger, E. M., and Coauthors, 2012: Climatic effects of 1950-2050 changes in US anthropogenic aerosols-Part 2: Climate response. Atmos. Chem. Phys., 12, 3349-3362, doi:10.5194/acp-12-3349-2012.

Lenderink, G., and E. van Meijgaard, 2008: Increase in hourly precipitation extremes beyond expectations from temperature changes. Nat. Geosci., 1, 511-514, doi:10.1038/ngeo262.

Levy, A. A. L., W. Ingram, M. Jenkinson, C. Huntingford, F. H. Lambert, and M. Allen, 2013: Can correcting feature location in simulated mean climate improve agreement on projected changes? Geophys. Res. Lett. Atmos., 40, 354-358, doi:10.1002/2012GL053964.

Levy, H., II, L. W. Horowitz, M. D. Schwarzkopf, Y. Ming, J.-C. Golaz, V. Naik, and V. Ramaswamy, 2013: The roles of aerosol direct and indirect effects in past and future climate change. J. Geophys. Res., 118, 4521-4532, doi:10.1002/jgrd.50192.

Liepert, B. G., J. Feichter, U. Lohmann, and E. Roeckner, 2004: Can aerosols spin down the water cycle in a warmer and moister world? Geophys. Res. Lett., 31, L06207, doi:10.1029/2003GL019060.

Liu, C., and R. P. Allan, 2012: Multisatellite observed responses of precipitation and its extremes to interannual climate variability. J. Geophys. Res., 117, D03101, doi:10.1029/2011JD016568.
- , and — 2013: Observed and simulated precipitation responses in wet and dry regions 1850-2100. Environ. Res. Lett., 8, 034002, doi:10.1088/1748 $-9326 / 8 / 3 / 034002$.

Liu, Z. Y., 2012: Dynamics of interdecadal climate variability: A historical perspective. J. Climate, 25, 1963-1995, doi:10.1175/2011JCLI3980.1.

Lu, J., G. Vecchi, and T. Reichler, 2007: Expansion of the Hadley cell under global warming. Geophys. Res. Lett., 34, L06805, doi:10.1029/2006GL028443.

Maidment, R. I., D. Grimes, R. P. Allan, E. Tarnavsky, M. Stringer, T. Hewison, R. Roebeling, and E. Black, 2014: The 30 year TAMSAT African Rainfall Climatology and Time Series (TARCAT) data set. J. Geophys. Res. Atmos., 119, $10619-10644$, doi:10.1002/2014JD021927.

Manabe, S., and R. T. Wetherald, 1980: On the distribution of climate change resulting from an increase in $\mathrm{CO}_{2}$ content of the atmosphere. J. Atmos. Sci., 37, 99-118, doi:10.1175/1520-0469(1980)037<0099:OT DOCC $>2.0 . C O ; 2$.

Marvel, K., and C. Bonfils, 2013: Identifying external influences on global precipitation. Proc. Natl. Acad. Sci. USA, 110, 19301-19306, doi:10.1073 /pnas.1314382110.

McVicar, T. M., and Coauthors, 2012: Global review and synthesis of trends in observed terrestrial near-surface wind speeds: Implications for evaporation. J. Hydrol., 416-417, 182-205, doi:10.1016/j.jhydrol.2011.10.024.

Meehl, G. A., and Coauthors, 2007: Global climate projections. Climate Change 2007: The Physical Science Basis, S. Solomon et al., Eds., Cambridge University Press, 747-845.

—, J. M. Arblaster, and W. D. Collins, 2008: Effects of black carbon aerosols on the Indian monsoon. J. Climate, 21, 2869-2882, doi:10.1175/2007JCLI1777.1. Menne, M. J., I. Durre, R. S. Vose, B. E. Gleason, and T. G. Houston, 2012: An overview of the Global Historical Climatology Network daily database. J. Atmos. Oceanic Technol., 29, 897-910, doi:10.1175 /JTECH-D-11-00103.1.

Michelson, D., and Coauthors, 2013: WMO initiative for the global exchange of radar data. 36th Conf. on Radar Meteorology, Breckenridge, CO, Amer. Meteor. Soc., 14B.8. [Available online at https://ams.confex.com/ams/36Radar/webprogram /Paper229067.html.]

Min, S., X. Zhang, and F. W. Zwiers, 2008: Humaninduced Arctic moistening. Science, 320, 518-520, doi:10.1126/science.1153468.

,,--- , and G. C. Hegerl, 2011: Human contribution to more intense precipitation extremes. Nature, 470, 378-381, doi:10.1038/nature09763. 
Ming, Y., and V. Ramaswamy, 2011: A model investigation of aerosol-induced changes in tropical circulation. $J$. Climate, 24, 5125-5133, doi:10.1175/2011JCLI4108.1.

Morice, C. P., J. J. Kennedy, N. A. Rayner, and P. D. Jones, 2012: Quantifying uncertainties in global and regional temperature change using an ensemble of observational estimates: The HadCRUT4 data set. J. Geophys. Res., 117, D08101, doi:10.1029/2011JD017187.

O'Gorman, P. A., 2012: Sensitivity of tropical precipitation extremes to climate change. Nat. Geosci., 5, 697-700, doi:10.1038/ngeo1568.

—, R. P. Allan, M. P. Byrne, and M. Previdi, 2012: Energetic constraints on precipitation under climate change. Surv. Geophys., 33, 585-608, doi:10.1007 /s10712-011-9159-6.

Osborn, T. J., 1997: Areal and point precipitation intensity changes: Implications for the application of climate models. Geophys. Res. Lett., 24, 2829-2832, doi:10.1029/97GL02976.

Pall, P., T. Aina, D. A. Stone, P. A. Stott, T. Nozawa, A. G. J. Hilberts, D. Lohmann, and M. R. Allen, 2011: Anthropogenic greenhouse gas contribution to flood risk in England and Wales in autumn 2000. Nature, 470, 382-385, doi:10.1038/nature09762.

Pendergrass, A. G., and D. L. Hartmann, 2012: Global-mean precipitation and black carbon in AR4 simulations. Geophys. Res. Lett., 39, L01703, doi:10.1029/2011GL050067.

— on global-mean precipitation change. J. Climate, 27, 757-768, doi:10.1175/JCLI-D-13-00163.1.

Peterson, T. C., and R. Vose, 1997: An overview of the global historical climatology network temperature database. Bull. Amer. Meteor. Soc., 78, 2837-2849, doi:10.1175/1520-0477(1997)078<2837:AOOTGH $>2.0 . \mathrm{CO} ; 2$.

— , P. A. Stott, and S. Herring, 2012: Explaining extreme events of 2011 from a climate perspective. Bull. Amer. Meteor. Soc., 93, 1041-1067, doi:10.1175 /BAMS-D-12-00021.1.

—, M. P. Hoerling, P. A. Stott, and S. Herring, Eds., 2013: Explaining extreme events of 2012 from a climate perspective. Bull. Amer. Meteor. Soc., 94, S1-S74, doi:10.1175/BAMS-D-13-00085.1.

Pierce, D. W., P. J. Gleckler, T. P. Barnett, B. D. Santer, and P. J. Durack, 2012: The fingerprint of humaninduced changes in the ocean's salinity and temperature fields. Geophys. Res. Lett., 39, L21704, doi:10.1029/2012GL053389.

Polson, D., G. C. Hegerl, R. P. Allan, and B. Balan Sarojini, 2013a: Have greenhouse gases intensified the contrast between wet and dry regions? Geophys. Res. Lett., 40, 4783-4787, doi:10.1002/grl.50923.
,-- , X. Zhang, and T. J. Osborn, 2013b: Causes of robust seasonal land precipitation changes. J. Climate, 26, 6679-6697, doi:10.1175/JCLI-D-12-00474.1.

_-, M. Bollasina, G. H. Hegerl, and L. J. Wilcox, 2014: Decreased monsoon precipitation in the Northern Hemisphere due to anthropogenic aerosols. Geophycs. Res Lett., 41, 6023-6029, doi:10.1002/2014GL06811.

Rawlins, M. A., and Coauthors, 2010: Analysis of the Arctic system for freshwater cycle intensification: Observations and expectations. J. Climate, 23, 5715-5737, doi:10.1175/2010JCLI3421.1.

Richter, I., and S. P. Xie, 2008: Muted precipitation increase in global warming simulations: A surface evaporation perspective. J. Geophys. Res., 113, D24118, doi:10.1029/2008JD010561.

Rotstayn, L. D., and U. Lohmann, 2002: Tropical rainfall trends and the indirect aerosol effect. J. Climate, 15, 2103-2116, doi:10.1175/1520 -0442(2002)015<2103:TRTATI>2.0.CO;2.

— B. B. Ryan, and J. E. Penner, 2000: Precipitation changes in a GCM resulting from the indirect effects of anthropogenic aerosols. Geophys. Res. Lett., 27, 3045-3048, doi:10.1029/2000GL011737.

— S. J. Jeffrey, M. A. Collier, S. M. Dravitzki, A. C. Hirst, J. I. Syktus, and K. K. Wong, 2012: Aerosol induced changes in summer rainfall an circulation in the Australasian region: A study using single-forcing climate simulations. Atmos. Chem. Phys. Discuss., 12, 5107-5188, doi:10.5194/acpd-12-5107-2012.

Sánchez-Lugo, J. A., W. M. Thiaw, and S. J. Weaver, 2014: Regional climates [in "State of the Climate in 2013"]. Bull. Amer. Meteor. Soc., 95 (7), S157-S213.

Santer, B. D., and Coauthors, 2007: Identification of human-induced changes in atmospheric moisture content. Proc. Natl. Acad. Sci. USA, 104, $15248-$ 15253, doi:10.1073/pnas.0702872104.

_, and Coauthors, 2009: Incorporating model quality information in climate change detection and attribution studies. Proc. Natl. Acad. Sci. USA, 106, 14778-14783, doi:10.1073/pnas.0901736106.

Scheff, J., and D. Frierson, 2012a: Twenty-first-century multimodel subtropical precipitation declines are mostly midlatitude shifts. J. Climate, 25, 4330-4347, doi:10.1175/JCLI-D-11-00393.1.

$\longrightarrow$, and,$- 2012 \mathrm{~b}$ : Robust future precipitation declines in CMIP5 largely reflect the poleward expansion of model subtropical dry zones. Geophys. Res. Lett., 39, L18704, doi:10.1029/2012GL052910.

Schubert, S., and Coauthors, 2009: A USCLIVAR project to assess and compare the responses of global climate models to drought-related SST forcing patterns: Overview and results. J. Climate, 22, 5251-5272, doi:10.1175/2009JCLI3060.1. 
Seager, R., and N. Naik, 2012: A mechanisms-based approach to detecting recent anthropogenic hydroclimate change. J. Climate, 25, 236-261, doi:10.1175 /JCLI-D-11-00056.1.

Seidel, D. J., Q. Fu, W. J. Randel, and T. J. Reichler, 2008: Widening of the tropical belt in a changing climate. Nat. Geosci., 1, 21-24, doi:10.1038/ngeo.2007.38.

Sherwood, S. C., R. Roca, T. M. Weckwerth, and N. G. Andronova, 2010: Tropospheric water vapour, convection and climate. Rev. Geophys., 48, RG2001, doi:10.1029/2009RG000301.

Shindell, D., A. Voulgarakis, G. Faluvegi, and G. Milly, 2012: Precipitation response to regional radiative forcing. Atmos. Chem. Phys., 12, 6969-6982, doi:10.5194 /acp-12-6969-2012.

Simmons, A. J., K. M. Willet, P. D. Jones, P. W. Thorne, and D. P. Dee, 2010: Low-frequency variations in surface atmospheric humidity, temperature, and precipitation: Inferences from reanalyses and monthly gridded observational data sets. J. Geophys. Res., 115, D01110, doi:10.1029/2009JD012442.

Skliris, N., R. Marsh, S. A. Josey, S. A. Good, C. Liu, and R. P. Allan, 2014: Salinity changes in the World Ocean since 1950 in relation to changing surface freshwater fluxes. Climate Dyn., 43, 709-736, doi:10.1007/s00382-014-2131-7.

Stott, P. A., R. T. Sutton, and D. M. Smith, 2008: Detection and attribution of Atlantic salinity changes. Geophys. Res. Lett., 35, L21702, doi:10.1029/2008GL035874.

— , N. P. Gillett, G. C. Hegerl, D. J. Karoly, D. A. Stone, X. Zhang, and F. Zwiers, 2010: Detection and attribution of climate change: A regional perspective. Wiley Interdiscip. Rev.: Climate Change, 1, 192-211, doi:10.1002/wcc.34.

Strachan, J., P. L. Vidale, K. Hodges, M. Roberts, and M.-E. Demory, 2013: Investigating global tropical cyclone activity with a hierarchy of AGCMs: The role of model resolution. J. Climate, 26, 133-152, doi:10.1175 /JCLI-D-12-00012.1.

Taylor, K. E., R. J. Stouffer, and G. A. Meehl, 2012: An overview of CMIP5 and the experiment design. Bull. Amer. Meteor. Soc., 93, 485-498, doi:10.1175 /BAMS-D-11-00094.1.

Terray, L., L. Corre, S. Cravatte, T. Delcroix, G. Reverdin, and A. Ribes, 2012: Near-surface salinity as nature's rain gauge to detect human influence on the tropical water cycle. J. Climate, 25, 958-977, doi:10.1175 /JCLI-D-10-05025.1.

Trenberth, K. E., 2011: Changes in precipitation with climate change. Climate Res., 47, 123-138, doi:10.3354 /cr00953.

—_, and A. Dai, 2007: Effects of Mount Pinatubo volcanic eruption on the hydrological cycle as an analog of geoengineering. Geophys. Res. Lett., 34, L15702, doi:10.1029/2007GL030524.

- , and J. T. Fasullo, 2013a: North American water and energy cycles. Geophys. Res. Lett., 40, 365-369, doi:10.1002/grl.50107.

$\longrightarrow$, and — 2013b: Regional energy and water cycles: Transports from ocean to land. J. Climate, 26, 7837-7851, doi:10.1175/JCLI-D-13-00008.1.

—, A. Dai, R. M. Rasmussen, and D. B. Parsons, 2003: The changing character of precipitation. Bull. Amer. Meteor. Soc., 84, 1205-1217, doi:10.1175/BAMS-849-1205.

—, J. Fasullo, and L. Smith, 2005: Trends and variability in column-integrated water vapor. Climate Dyn., 24, 741-758, doi:10.1007/s00382-005-0017-4.

,-- , and J. Mackaro, 2011: Atmospheric moisture transports from ocean to land and global energy flows in reanalyses. J. Climate, 24, 4907-4924, doi:10.1175/2011JCLI4171.1.

_- A. Dai, G. van der Schrier, P. D. Jones, J. Barichivich, K. R. Briffa, and J. Sheffield, 2014: Global warming and changes in drought. Nat. Climate Change, 4, 17-22, doi:10.1038/nclimate2067.

Utsumi, N. S., S. Seto, S. Kanae, E. E. Maeda, and T. Oki, 2011: Does higher surface temperature intensify extreme precipitation? Geophys. Res. Lett., 38, L16708, doi:10.1029/2011GL048426

Vecchi, G. A., B. J. Soden, A. T. Wittenberg, I. M. Held, A. Leetmaa, and M. J. Harrison, 2006: Weakening of tropical Pacific atmospheric circulation due to anthropogenic forcing. Nature, 441, 73-76, doi:10.1038 /nature04744.

Vicente-Serrano, S. M., C. Azorin-Molina, A. SanchezLorenzo, E. Morán-Tejeda, J. Lorenzo-Lacruz, J. Revuelto, J. I. López-Moreno, and F. Espejo, 2014: Temporal evolution of surface humidity in Spain: Recent trends and possible physical mechanisms. Climate Dyn., 42, 2655-2674, doi:10.1007/s00382-013-1885-7. Wan, H., X. Zhang, F. W. Zwiers, and H. Shiogama, 2013: Effect of data coverage on the estimation of mean and variability of precipitation at global and regional scales. J. Geophys. Res. Atmos., 118, 534-546, doi:10.1002/jgrd.50118.

Westra, S., L. V. Alexander, and F. W. Zwiers, 2013: Global increasing trends in annual maximum daily precipitation. J. Climate, 26, 3904-3918, doi:10.1175 /JCLI-D-12-00502.1.

—, and Coauthors, 2014: Future changes to the intensity and frequency of short-duration extreme rainfall. Rev. Geophys., 52, 522-555, doi:10.1002/2014RG000464.

WHO/UNICEF, 2011: Drinking water equity, safety and sustainability: Thematic report on drinking water. 
JMP Thematic Rep. on Drinking Water 2011, 62 pp. [Available online at www.wssinfo.org/fileadmin /user_upload/resources/report_wash_low.pdf.]

Wilcox, L. J., E. J. Highwood, and N. J. Dunstone, 2013: Influence of aerosol on multi-decadal variations of historical global climate. Environ. Res. Lett., 8, 024033, doi:10.1088/1748-9326/8/2/024033.

Willett, K. M., N. P. Gillett, P. D. Jones, and P. W. Thorne, 2007: Attribution of observed surface humidity changes to human influence. Nature, 449, 710-712, doi:10.1038/nature06207.

_ , P. D. Jones, P. W. Thorne, and N. P. Gillett, 2010: A comparison of large scale changes in surface humidity over land in observations and CMIP3 GCMs. Environ. Res. Lett., 5, 025210, doi:10.1088/17489326/5/2/025210.

—, C. N. Williams Jr., R. J. H. Dunn, P. W. Thorne, S. Bell, M. de Podesta, P. D. Jones, and D. E. Parker, 2013: HadISDH: An updated land surface specific humidity product for climate monitoring. Climate Past, 9, 657-677, doi:10.5194/cp-9-657-2013.

—, D. I. Berry, and A. Simmons, 2014: Surface humidity [in "State of the Climate in 2013"]. Bull. Amer. Meteor. Soc., 95, S19-S20, doi:10.1175/2014BAMSS tateoftheClimate.1.

Winterrath, W. Rosenow, and E. Weigl, 2012a: On the DWD quantitative precipitation analysis and nowcasting system for real-time application in German flood risk management. Weather Radar and Hydrology, IAHS Publ. 351, 323-329.

— , E. Weigl, M. Hafer, and A. Becker, 2012b: Towards a 10-year climatology of radar-based precipitation analyses. Proc. Seventh European Conf. on Radar in Meteorology and Hydrology, Toulouse, France, ERAD, 44 QPE.

World Water Assessment Program, 2003: Water for People, Water for Life: A Joint Report by the Twenty Three UN Agencies Concerned with Freshwater. UNESCO and Berghahn Books, 576 pp.

Wu, P., R. Wood, and J. Ridley, 2010: Temporary acceleration of the hydrological cycle in response to a $\mathrm{CO}_{2}$ rampdown. Geophys. Res. Lett., 37, L12705, doi:10.1029/2010GL043730.

—, N. Christidis, and P. Stott, 2013: Anthropogenic impact on Earth's hydrological cycle. Nat. Climate Change, 3, 807-810, doi:10.1038/nclimate1932.
Xie, P., and P. A. Arkin, 1998: Global monthly precipitation estimates from satellite-observed outgoing longwave radiation. J. Climate, 11, 137-164, doi:10.1175/1520-0442(1998)011<0137:GMPEFS >2 .0.CO;2.

Xie, S.-P., C. Deser, G. A. Vecchi, J. Ma, H. Teng, and A. T. Wittenberg, 2010: Global warming pattern formation: Sea surface temperature and rainfall. $J$. Climate, 23, 966-986, doi:10.1175/2009JCLI3329.1.

Yin, J. H., 2005: A consistent poleward shift of the storm tracks in simulations of 21st century climate. Geophys. Res. Lett., 32, L18701, doi:10.1029/2005GL023684.

Yu, L., and R. A. Weller, 2007: Objectively analyzed air-sea heat fluxes for the global ice-free oceans (1981-2005). Bull. Amer. Meteor. Soc., 88, 527-539, doi:10.1175/BAMS-88-4-527.

_, X. Jin, and R. A. Weller, 2008: Multidecade global flux datasets from the objectively analyzed air-sea fluxes (OAFlux) project: Latent and sensible heat fluxes, ocean evaporation, and related surface meteorological variables. Woods Hole Oceanographic Institution OAFlux Project Tech. Rep. OA-2008-01, 64 pp.

Zelinka, M. D., T. Andrews, P. M. Forster, and K. E. Taylor, 2014: Quantifying components of aerosolcloud-radiation interactions in climate models. J. Geophys. Res. Atmos., 119, 7599-7615, doi:10.1002/2014JD021710.

Zhang, X., F. W. Zwiers, G. C. Hegerl, F. H. Lambert, N. P. Gillett, S. Solomon, P. A. Stott, and T. Nozawa, 2007: Detection of human influence on twentiethcentury precipitation trends. Nature, 448, 461-465, doi:10.1038/nature06025.

_ , H. Wan, F. W. Zwiers, G. C. Hegerl, and S.-K. Min, 2013: Attributing intensification of precipitation extremes to human influence. Geophys. Res. Lett., 40, 5252-5257, doi:10.1002/grl.51010.

Zhao, T., A. Dai, and J. Wang, 2012: Trends in tropospheric humidity from 1970-2008 over China from a homogenized radiosonde dataset. J. Climate, 25, 4549-4567, doi:10.1175/JCLI-D-11-00557.1.

Zolina, O., C. Simmer, S. K. Gulev, and S. Kollet, 2010: Changing structure of European precipitation: Longer wet periods leading to more abundant rainfalls. Geophys. Res. Lett., 37, L06704, doi:10.1029/2010GL042468. 
